\title{
Enriched-Uranium Feed Costs for the High-Temperature Gas-Cooled Reactor: Trends and Comparison with Other Reactor Concepts
}

\section{MASIER}

W. E. Thomas 


\section{DISCLAIMER}

This report was prepared as an account of work sponsored by an agency of the United States Government. Neither the United States Government nor any agency Thereof, nor any of their employees, makes any warranty, express or implied, or assumes any legal liability or responsibility for the accuracy, completeness, or usefulness of any information, apparatus, product, or process disclosed, or represents that its use would not infringe privately owned rights. Reference herein to any specific commercial product, process, or service by trade name, trademark, manufacturer, or otherwise does not necessarily constitute or imply its endorsement, recommendation, or favoring by the United States Government or any agency thereof. The views and opinions of authors expressed herein do not necessarily state or reflect those of the United States Government or any agency thereof. 


\section{DISCLAIMER}

Portions of this document may be illegible in electronic image products. Images are produced from the best available original document. 
Printed in the United States of America: Available from National Technical Information Service

U.S. Department of Commerce

5285 Port Royal Road, Springfield, Virginia 22161

Price: Printed Copy $\$ 4.00 ;$ Microfiche $\$ 2.25$

This report was prepared as an account of work sponsored by the United States Government. Neither the United States nor the Energy Research and Development Administration, nor any of their employees, nor any of their contractors, subcontractors, or their employees, makes any warranty, express or implied, or assumes any legal liability or responsibility for the accuracy, completeness or usefulness of any information, apparatus, product or process disclosed, or represents that its use would not infringe privately owned rights. 
ORNL/TM-5270

$$
\begin{aligned}
& \text { UC-77 - } \text { Gas-Cooled Reactor } \\
& \text { Technology }
\end{aligned}
$$

Contract No. W-7405-eng-26

$$
\text { Reactor Division }
$$

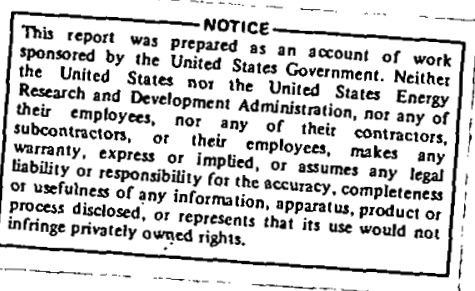

\title{
ENRICHED-URANIUM FEED COSTS FOR THE HIGH-TEMPERATURE GAS-COOLED REACTOR: TRENDS AND COMPARISON - WITH OTHER REACTOR CONCEPTS
}

W. E. Thomas

APRIL 1976

NOTICE: This document contains information of a preliminary nature and was prepared primarily for internal use at the Oak Ridge National Laboratory. It is subject to revision or correction and therefore does not represent a final report.

\author{
OAK RIDGE NATIONAL LABORATORY \\ Oak Ridge, Tennessee 37830 \\ operated by \\ UNION CARBIDE CORPORATION \\ for the \\ ENERGY RESEARCH AND DEVELOPMENT ADMINISTRATION
}


THIS PAGE

\section{WAS INTENTIONALLY LEFT BLANK}


CONTENTS

$\underline{\text { Page }}$

ACKNOWLEDGMENTS $\ldots \ldots \ldots \ldots \ldots \ldots \ldots \ldots \ldots \ldots \ldots \ldots \ldots \ldots \ldots \ldots \ldots \ldots \ldots \ldots$

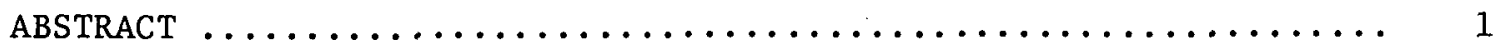

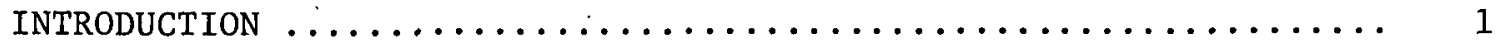

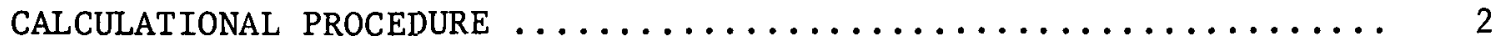

TRANSACTION TAILS ASSAY $\ldots \ldots \ldots \ldots \ldots \ldots \ldots \ldots \ldots \ldots \ldots \ldots \ldots \ldots \ldots \ldots \ldots \ldots \ldots \ldots \ldots$

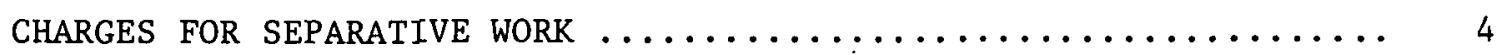

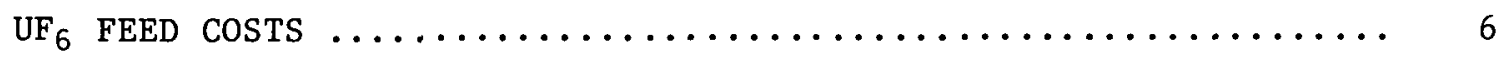

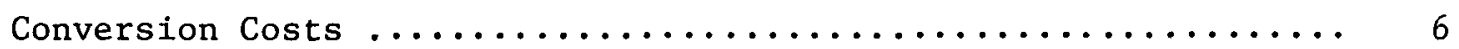

Ore (Yellowcake) Costs $\ldots \ldots \ldots \ldots \ldots \ldots \ldots \ldots \ldots \ldots \ldots \ldots \ldots \ldots \ldots$

UNIT COSTS AND COST COMPARISON $\ldots \ldots \ldots \ldots \ldots \ldots \ldots \ldots \ldots \ldots \ldots$

Historical Trends in Feed/SwU Cost Ratio ................ 9

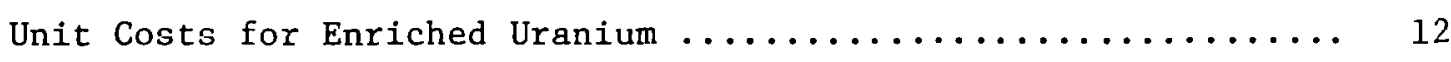

Loading Costs for HTGR vs PWR .................. 17

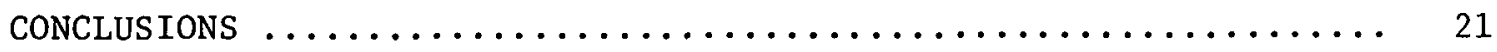

APPENDIX A. UNIT COSTS FOR ENRICHED URANIUM $\ldots \ldots \ldots \ldots \ldots \ldots \ldots . \ldots \ldots$

Indifference Feed/SWU Cost Ratio ................. 30

APPENDIX B. HISTORICAL COSTS FOR ORE CONCENTRATES $\ldots \ldots \ldots \ldots \ldots .33$

AEC Prices Paid for Ore Concentrates $\left(\mathrm{U}_{3} \mathrm{O}_{8}\right) \ldots \ldots \ldots \ldots \ldots \ldots \ldots \ldots$

Commercial Prices Paid for Ore Concentrates $\left(\mathrm{U}_{3} \mathrm{O}_{8}\right) \ldots \ldots \ldots \ldots .34$

Surveys and Projections ......................... 35

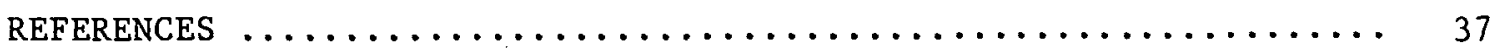


THIS PAGE

WAS INTENTIONALLY

LEFT BLANK 


\section{ACKNOWLEDGMENTS}

The author appreciates the help and advice from M. L. Myers in locating some of the historical unit cost data. Appreciation is also expressed to L. L. Bennett, M. L. Tobias, and B. E. Prince for their review of the report. In addition, thanks are due to Ann Ragan and Myrtleen Sheldon for their editorial assistance; Frances Burkhalter for preparing the figures; and Margaret Wilson for typing the final copy. 


\title{
ENRICHED-URANIUM FEED COSTS FOR THE HIGH-TEMPERATURE GAS-COOLED REACTOR: TRENDS AND COMPARISON WITH OTHER REACTOR CONCEPTS
}

W. E. Thomas

\begin{abstract}
This report discusses each of the components that affect the unit cost for enriched uranium; that is, ore costs, $\mathrm{U}_{3} \mathrm{O}_{8}$ to $\mathrm{UF}_{6}$ conversion cost, costs for enriching services, and changes in transaction tails assay. Historical trends and announced changes are included. Unit costs for highly enriched uranium $(93.15 \% 235 \mathrm{U})$ and for low-enrichment uranium (3.0, 3.2 , and $3.5 \% 235 \mathrm{U}$ ) are displayed as a function of changes in the above components and compared. It is demonstrated that the trends in these cost components will probably result in significantly less cost increase for highly enriched uranium than for low-enrichment uranium - hence favoring the HighTemperature Gas-Cooled Reactor.

Key words: HTGR, uranium, enriched materials, costs.
\end{abstract}

\section{INTRODUCTION}

The price that a utility, operating a High-Temperature Gas-Cooled Reactor (HTGR), must pay per kilogram of enriched uranium $\left(93.15 \%{ }^{235} \mathrm{U}\right)$ received from a gaseous diffusion cascade is a function of the following:

1. transaction tails assay,

2. cost for a unit of separative work (SWU),

3. unit cost paid for ore concentrates $\left(\mathrm{U}_{3} \mathrm{O}_{8}\right)$ and associated cost for converting $\mathrm{U}_{3} \mathrm{O}_{8}$ to $\mathrm{UF}_{6}$.

Fach of the above itcms is expected to change with time. 'l'his report examines the impact these changes may have on future costs for HTGR fresh feed and compares HTGR feed costs using highly enriched uranium with feed costs for other reactor types fueled with low-enrichment uranium.

The following section describes the method used to compute and compare feed costs, and subsequent sections discuss the announced changes in 
transaction tails assay, and historical costs for SWU, ore concentrates, and conversion costs. The final sections are confined to the discussion of feed costs and cost comparisons.

\title{
CALCULATIONAL PROCEDURE
}

\begin{abstract}
Reactor feed cost $C$, in dollars paid for fresh uranium enriched in ${ }^{235} \mathrm{U}$ content to some enrichment e, can be calculated from the following
\end{abstract} expression:

$$
c=W C_{e}=W\left(c_{I} x_{I}+c_{y} x_{s}\right),
$$

where $\mathrm{W}$ is the amount of enriched uranium required per loading $(\mathrm{kg})$ and $\mathrm{C}_{\mathrm{e}}$ is a unit cost $(\$ / \mathrm{kg})$ for enriched uranium. The loading $W$ is fixed by reactor design; $C_{e}$ is a function of the unit cost for natural uranium $C_{f}$, the feed component $x_{f}$, the unit cost for enriching services $C_{s}$, and the separative work component $X_{S}$. Feed and separative work components depend entirely on the $235 \mathrm{U}$ content in product, normal feed, and tails at the gaseous diffusion plant [see Eqs. (A2) and (A3) in Appendix A]. The unit cost for natural uranium is the sum of the unit cost for orc concentrates $\left(\mathrm{U}_{3} \mathrm{O}_{8}\right)$ and the unit cost for conversion to $\mathrm{UF}_{6}$. As used in Eq. (1), $\mathrm{C}_{\mathrm{f}}$ represents a cost delivered to the cascade feed station, including sampling and transportation charges and accounting for processing losses.

Consider two different reactors producing the same thermal power. One reactor requires a loading of $\mathrm{W}$ kilograms of enriched uranium per year at enrichment el, costing $C$ dollars per loading. The other reactor is fueled with enriched uranium at enrichment $e 2$ and requires a loading of $W^{\prime}$ kilograms per year, costing $C^{\prime}$ dollars per loading. The ratio of cost per loading is

$$
\frac{C}{C^{\prime}}=\frac{C_{e 1} W}{C_{e 2} W^{\prime}} \propto \frac{C_{e 1}}{C_{e 2}}=\frac{x_{f}}{X_{f}^{\prime}}\left[\frac{\left(C_{f} / C_{s}\right)+\left(x_{s} / x_{f}\right)}{\left(C_{f} / C_{s}\right)+\left(X_{s}^{\prime} / X_{f}^{\prime}\right)}\right] .
$$

Since the quantities $W$ and $W^{\prime}$ are the amounts of enriched uranium charged to maintain criticality during reactor operation and are fixed by reactor design, the ratio of loading costs becomes proportional to the 
ratio of unit costs paid for enriched uranium at each enrichment el and e2 being investigated. The ratio of loading costs depends on the ratio of unit price paid for natural uranium feed $C_{f}$ to unit charge for enrichment services $C_{s}$ (hereafter referred to as the feed/SWU cost ratio). In Eq. (2), feed components and separative work components shown with primes refer to enrichment $\mathrm{e} 2$, and unprimed quantities refer to enrichment e1.

Equation (2) provides a convenient means for comparing costs for purchasing highly enriched uranium to fuel an HTGR with those of low-enrichment uranium for other reactor types (e.g., PWRs), considering changes in transactions tails assay and changes in unit costs for ore, conversion, and enriching services.

\section{TRANSACTION TAILS ASSAY}

In a gaseous diffusion plant the term operating tails $x_{w}$ denotes the weight fraction of $235 \mathrm{U}$ contained in "depleted" uranium (weight fraction somewhat less than natural uranium). The transaction tails assay lists values for $\mathrm{xw}$ specified by the U.S. Energy Research and Development Administration (ERDA) (formerly AEC) in documents such as the Federal Register for use in computing feed requirements and separative work units. In the event that the transaction tails assay is specified somewhat lower than that of the operating tails, the government makes up the difference in feed requirements from reserves.

The transaction tails assay influences the values for $\mathrm{X}$ in Eqs. (1) and (2). An increase in the transaction tails assay increases the feed component (i.e., $X_{f}$ and $X_{f}^{\prime}$ ) but decreases the separative work component (t.e., $X_{s}$ and $X_{s}^{\prime}$ ) [see Eqs. (A2) and (A3) and Table A1 of Appendix A].

In June 1975, ERDA announced the following schedule of values for the transaction tails assay: ${ }^{1}$

$\begin{array}{lc}\frac{x_{w}}{0.002} & \text { Effective date } \\ 0.0025 & \text { Through } 9-30-77 \\ 0.00275 & 10-1-77 \\ 0.003 & 7-1-79 \\ 10-1-81\end{array}$


CHARGES FOR SEPARATIVE WORK

Events $^{2}$ leading to ownership by private industry of special nuclear materials and toll enrichment are summarized here. The Atomic Energy Act of 1954 permitted private industry to own all components of a nuclear power plant except the enriched-uranium fuel and the plutonium produced in the reactor. Possession and use of special nuclear materials by private industry was under 11cense from the USAEC. Fuel costs were paid in the form of a use charge. The Private Ownership of Special Nuclear Materials Act, approved Aug. 26, 1964, eliminated this exclusion and permitted private industry to own the enriched uranium and plutonfum. In 1966, the USAEC published the criteria under which it would perform toll enrichment of privately owned uranium and in 1967 published the first schedule of charges for this service. Toll enrichment of privately owned uranium began Jan. 1, 1969.

Under this concept, the USAEC received privately owned uranium and performed $235 \mathrm{U}$ enrichment services for which the customer paid a "toll" charge. The charges per swu that appeared in the vartous lssues of Llie Federal Register are given in l'able 1. Separate charges according to contract type tirst appeared in the Federal Register Aug. 9, 1973. In the Federal Register, the two contract types are referred to as "requirements type" and "other than requirements type." The term "fixed-commitment contract" has sometimes been used to mean "other than requirements-type contract." ERDA ${ }^{3}$ defined the contract types as follows: "Under a fixedcommitment contract, a customer specifies in advance the amount of enriching services he requires, thus obligating himself to a 'fixed' amount of these services. Under a requirements-type contract, ER̈DA is obligated, within limits, to provide a customer with the amount of enriching services he requires."

SWU costs from Table 1, together with the announced approximate increase $^{3}$ ( $\left.\$ 76\right)$ for fixed-commitment contracts, are plotted in Fig. 1 . The true costs beyond December 1975 will depend on action on the ERDA draft bill which was forwarded to Congress on June 24, 1975. 


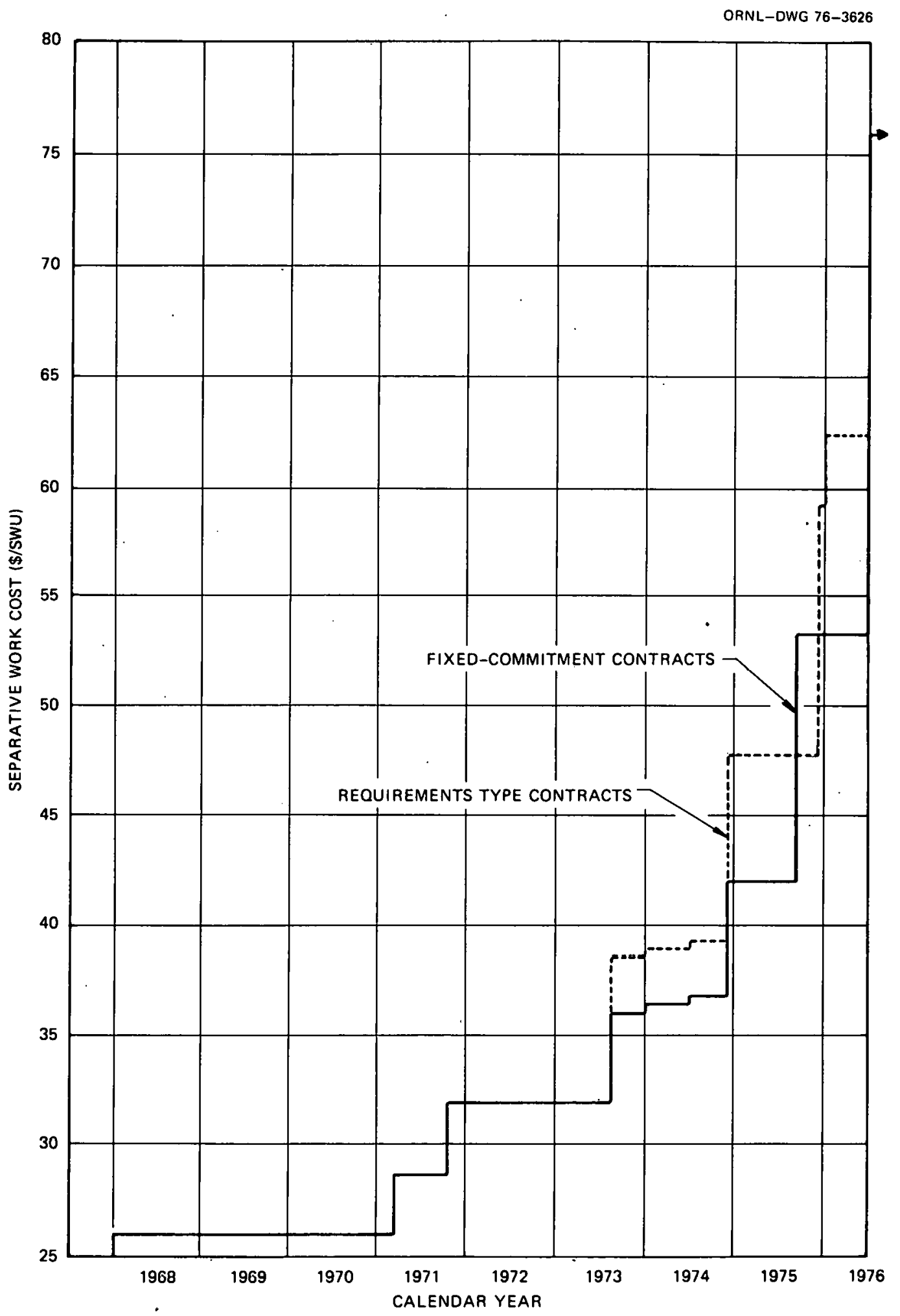

Fig. 1. Charge per eeparative work unit - current dollare. (See Ref. 3 and Table 1.) 
Table 1. Costs for enrichment services - historical data

\begin{tabular}{|c|c|c|c|}
\hline $\begin{array}{l}\text { Cost per } \\
\text { SwU } \\
\text { (current } \\
\text { collars) }\end{array}$ & $\begin{array}{l}\text { Contract } \\
\text { type }\end{array}$ & Effective date & $\begin{array}{l}\text { Source: Federal Register } \\
\text { (volume, page, date) }\end{array}$ \\
\hline 26.0 & & Jan. 1, 1968 & 32FR16289; Nov. 29, 1967 \\
\hline 28.70 & & Feb. 22, 1971 & 35FR13547; Aug. 25, 1970 \\
\hline 32.00 & & Sept. 6, 1971 & 36FR4563; Mar. 9, 1971 \\
\hline 38.50 & & Aug. 14,1973 & 38FR4432; Feb. 14, 1973 \\
\hline $\begin{array}{l}38.50 \\
36.00\end{array}$ & $\begin{array}{l}R \\
F\end{array}$ & $\left.\begin{array}{l}\text { Aug. } 14,1973 \\
\text { Aüg. } 14,1973\end{array}\right)$ & \multirow{3}{*}{ 38FR21518; Aug. 9, 1973} \\
\hline $\begin{array}{l}38.90 \\
36.40\end{array}$ & $\begin{array}{l}\mathrm{R} \\
\mathrm{F}\end{array}$ & $\begin{array}{ll}\text { Jan. } 1, & 1974 \\
\text { Jan. } 1,1974\end{array}$ & \\
\hline $\begin{array}{l}39.30 \\
36.80\end{array}$ & $\begin{array}{l}\mathrm{R} \\
\mathrm{F}\end{array}$ & $\begin{array}{ll}\text { July } 1, & 1974 \\
\text { Jul.y } 1, & 1974\end{array}$ & \\
\hline $\begin{array}{l}47.80 \\
42.10\end{array}$ & $\begin{array}{l}\mathrm{R} \\
\mathrm{F}\end{array}$ & $\left.\begin{array}{ll}\text { Dec. } 18, & 1974 \\
\text { Dec. } 18, & 1974\end{array}\right\}$ & 39FR22182; June 20, 1974 \\
\hline 53.35 & F & Aug. 20, 1975 & 40FR26060; June 20, 1975 \\
\hline $60.95^{\mathrm{b}}$ & $\mathrm{R}$ & Dec. 18,1975 & 40FR26061; June 20, 1975 \\
\hline
\end{tabular}

${ }^{a}{ }_{R}=$ requirements type; $F=$ fixed commitment.

${ }^{b}$ or ceiling charge, whichever is less.

$\mathrm{UF}_{6}$ FEED COSTS

The unit cost for uranium contained in $\mathrm{UF}_{h}$ feed to a gaseous diffusion plant is the oum of the unit coot for ore concentratco and the unit coet for converting $\mathrm{U}_{3} \mathrm{O}_{8}$ to $\mathrm{UF}_{6}$. Costs for conversion and for ore concentrates are discussed separately below.

\section{Conversion Costs}

As of 1974, there were two commercial facilities in the U.S. capable of converting ore concentrates to $\mathrm{UF}_{6}$. One is the Allied Chemical plant 
at Metropolis, I11. (capacity 14,000 tons/year), and the other is the KerrMcGee Nuclear plant at Sequoyah, 0k1a. (5000 tons/year, with plans to increase future capacity to 10,000 tons/year).${ }^{4}$ Allied's base charge, $\$ 2.293$ per kilogram of uranium, is referenced to year 1965; Kerr-McGee's base charge, $\$ 2.49$ per kilogram, has a base date of $1967 . .^{2}$ Both rates are subject to escalation. It was estimated ${ }^{2}$ as of Mar. 31, 1970, that the KerrMcGee escalated rate, which includes sampling of ore concentrates and transportation of $\mathrm{UF}_{6}$ to the gaseous diffusion plant, was $\$ 2.74 / \mathrm{kg}$; $\mathrm{Al}-$ lied's escalated rate, for conversion only, was $\sim \$ 2.64 / \mathrm{kg}$. Lucius Pitkin, Inc., located adjacent to Allied's Metropolis plant, was sampling ore concentrates $^{2}$ (1970) for $\$ 47.95$ per gross ton or $\sim 6.2 \nless / \mathrm{kg}$.

Conversion charges were reported ${ }^{4}$ to be running between $\$ 3.00$ and $\$ 3.50$ per kilogram in 1974, with future charges from new plants expected to be significantly higher because of increased construction çosts and higher interest rates.

Conversion costs in late 1975 or early 1976 charged by Canada's Eldorado Nuclear ${ }^{5}$ were indicated to be about $\$ 1.50$ per pound of $\mathrm{U}_{3} \mathrm{O}_{8}(\sim \$ 3.90$ per kilogram of uranium).

\section{Ore (Yellowcake) Costs}

The trends in unit costs for $\mathrm{U}_{3} \mathrm{O}_{8}$ concentrates are shown in Fig. 2. These data, in current dollars, were obtained from the literature.5-12,17-34 The detailed unit cost data appearing in the figure are discussed in Appendix в. An attempt was made to obtain at least one quotation of the price paid by the former USAEC during each year for the years 1959 through 1970 and to obtain as much unit cost data as practical to indicate the range of prices paid for yellowcake on the open, free, or commercial market.

The USAEC's uranium procurement program ${ }^{2}$ extended over the 29-year period 1942 to 1970, inclusive. The average price paid by the government during that time was $\sim \$ 9 / \mathrm{lb}(\$ 19.85 / \mathrm{kg}) \mathrm{U}_{3} 0_{8}$, with $\sim 54 \%$ of the total quantity, or $\sim 176,000$ tons $\left(159.6 \times 10^{6} \mathrm{~kg}\right)$ of $\mathrm{U}_{3} 0_{8}$, having been derived from domestic sources. The last foreign purchase commitment terminated in 1966, the year that also saw the first commercial sales of uranium concentrates. 


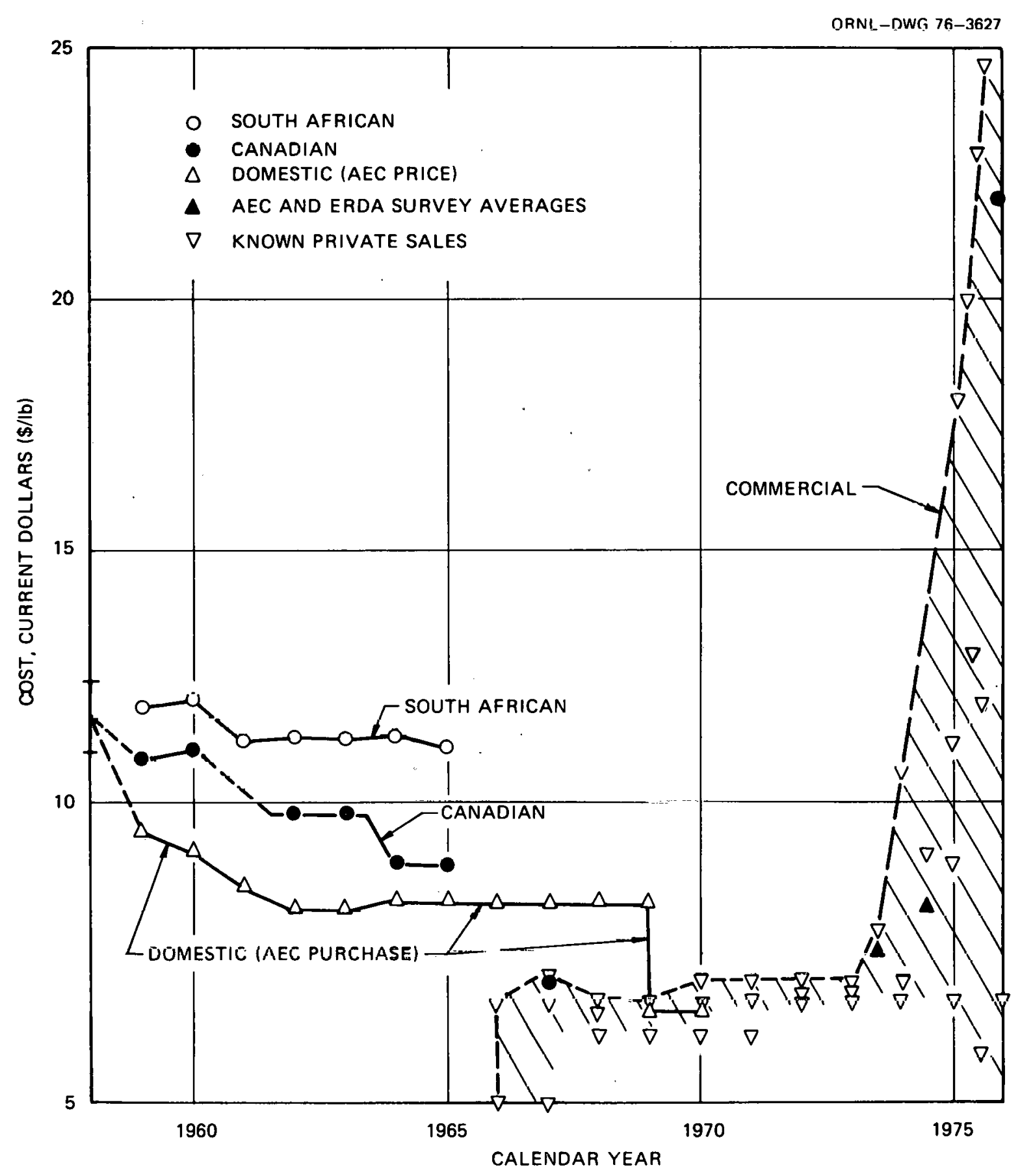

Fig. 2. Yellowcake prices (histurical). 
UNIT COSTS AND COST COMPARISON

The scope of this analysis is limited to costs for fresh enriched uranium produced in a gaseous diffusion plant and to a fresh fuel purchase cost comparison between reactors using highly enriched uranium and reactors using low-enrichment uranium. As indicated by Eq. (2), the ratio of reactor loading costs paid for fresh fuel is proportional to the ratio of unit costs which must be paid for enriched uranium at each of the two fuel enrichments being investigated. Once the two fuel enrichments have been selected (e.g., 0.9315 and 0.032) and a transaction tails assay has been specified (e.g., $0.002,0.0025$, etc.), the ratio of unit costs for enriched uranium is entirely dependent on variations in the feed/SWU cost ratio, defined as dollars per kilogram of natural uranium feed divided by dollars per SWU enriching charge.

\section{Historical Trends in Feed/SWU Cost Ratio}

Figure 3 shows the variation in feed/SWU cost ratio during calendar years 1968 through the third quarter of 1975. Costs for enriching services ( $\$ /$ SWU) are the same as those shown in Fig. 1, but only charges for fixedcommitment contracts are used in the latter years. Natural uranium feed costs at the cascade feed station were computed using annual commercial high and low unit costs for yellowcake (Fig. 2) and current conversion unit costs discussed in the previous section. Also shown in Fig. 3 are some feed/sWT cost ratios using specific unit coete for yellowcake. In 1968, the USAEC was paying $\$ 8.00 / \mathrm{lb} \mathrm{U}_{3} 0_{8}(\$ 17.64 / \mathrm{kg})$, whereas prices paid on the early commercial market were somewhat less. The average price paid by USAEC $^{6}$ for yellowcake during 1969 and 1970 was $\$ 5.85 / 1 \mathrm{~b}$ (\$12.90/kg), which was within the range of ore prices on the commercial market. The USAEC averages shown for years 1973 and 1974 are results from these surveys, which reflect average prices paid for yellowcakc during those years and include contracts which had been written several years prior. The average yellowcake price ${ }^{7}$ for 1973 was $\$ 7.10 / 1 b \quad \mathrm{U}_{3} 0_{8}(\$ 15.66 / \mathrm{kg})$, increasing $^{8}$ to $\$ 7.90 / 1 \mathrm{~b}(\$ 17.42 / \mathrm{kg})$ for 1974 . Western Nuclear ${ }^{9}$ received a letter of intent for 1974 deliveries at $\$ 9 / 1 \mathrm{~b}(\$ 19.85 / \mathrm{kg})$ and $\$ 10 / 1 \mathrm{~b}(\$ 22.05 / \mathrm{kg})$ 


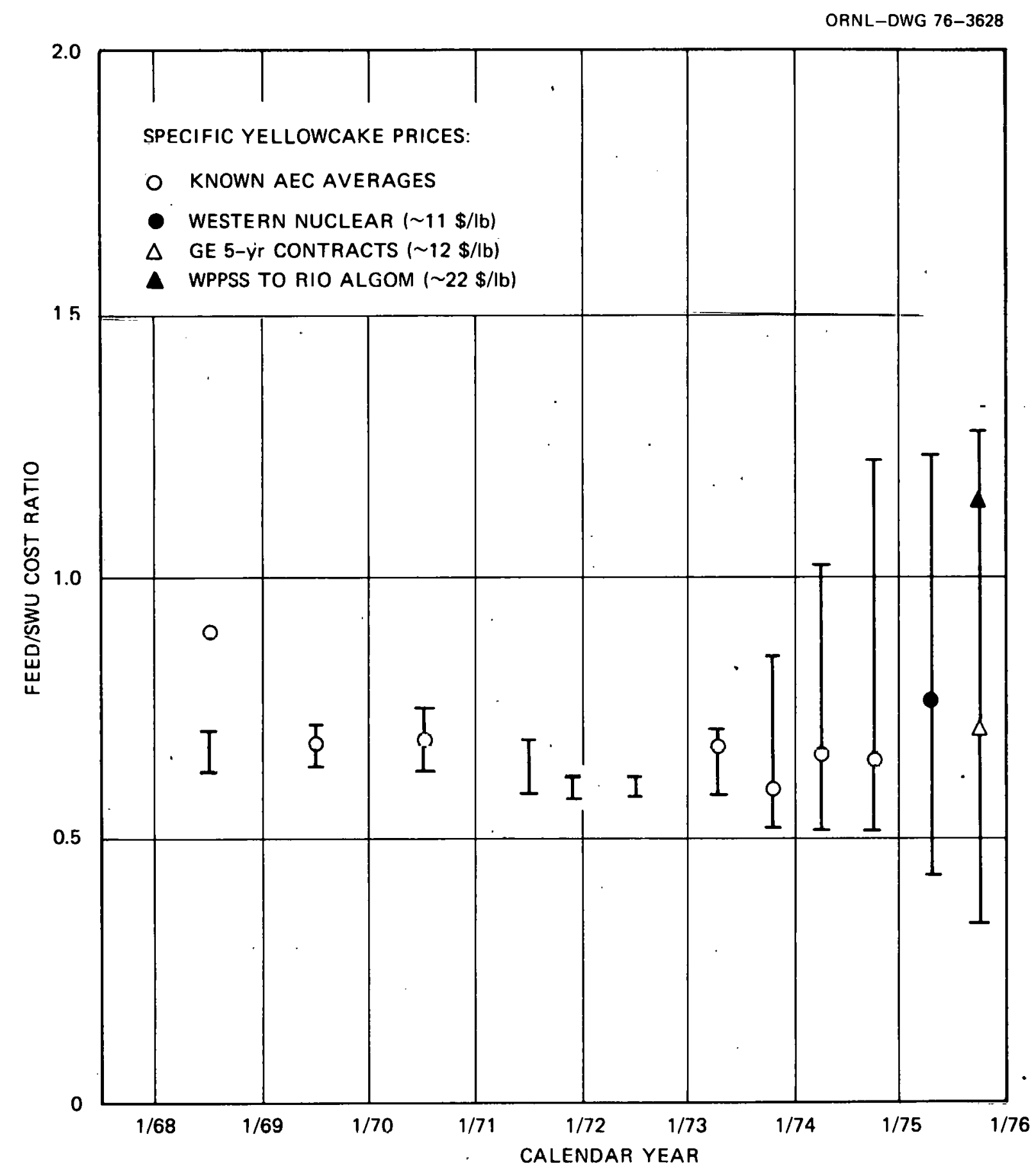

Fig. 3. Ratio of $\mathrm{UF}_{6}$ feed cost to cost per SWU. 
for 1975 deliveries subject to escalation $(\sim \$ 11 / 1$ b or $\sim \$ 24.26 / \mathrm{kg}$ assuming $10 \%$ escalation rate). General Electric ${ }^{10}$ was offering small-scale producers slightly more than $\$ 12 / 1 \mathrm{~b}(\$ 26.46 / \mathrm{kg})$ during the last half of 1975 , whereas Washington Public Power Supply System ${ }^{11}$ had awarded Canada's Rio Algom a contract for late 1975 and 1976 delivery at $\$ 22 / 1 b$ (\$48.51/kg).

It must be remembered that during the years from 1968 to 1975, enrichment costs increased from $\$ 26 /$ SWU in 1968 to $\$ 53.35 /$ SWU effective Aug. 20, 1975, for fixed-commitment contracts. Conversion costs also increased during the same period from $\sim \$ 2.50$ to $\sim \$ 3.90 / \mathrm{kg}$.

The average feed/SWU cost ratio (Fig. 3) during. the years 1971 to 1974 was approximately 0.63. The years 1974 and 1975 show the range between high and low to be expanding, with low values reflecting cheap ore costs from long-standing contracts and high values generally reflecting the current yellowcake market. The present trend in feed/SWU cost ratio appears to be upward because ore costs are rising faster than enriching costs. The upward trend in ore costs from a depressed market can be appreciated by considering that the reported pricel2 for concentrates during 1955 to 1958 was $\$ 12.38 / 1 \mathrm{~b}(\$ 27.30 / \mathrm{kg})$, or approximately $\$ 30 / 1 \mathrm{~b}(\$ 66.15 / \mathrm{kg})$ in equivalent 1975 dollars. Using the $\$ 30 / 1 \mathrm{~b}(\$ 66.15 / \mathrm{kg})$ and $\$ 53.35 / \mathrm{swU}$ costs implies a feed/SWU cost ratio of $\sim 1.5$, or $\sim 1.1$ if the announced $\sim \$ 76 /$ SWU enriching cost is used. 1

It is not the purpose of this report to forecast future costs for yellowcake, conversion, and enrichment service and hence trends in feed/SWU cost ratio; however, it is interesting to note that future prices for the above components from at least one such projection ${ }^{13}$ indicate that feed/SWU cost ratios will continue increasing for at least the next two decades. The results projected by Reichle ${ }^{13}$ for $\mathrm{UF}_{6}$ cost (feed costs) and for enrichment services are reproduced below.

\begin{tabular}{lrrrrr} 
& 1975 & 1980 & 1985 & 1990 & 1995 \\
\cline { 2 - 6 } Feed cost, \$/kg U & 69 & 96 & 135 & 189 & 265 \\
Enrichment, \$/SWU & 80 & 98 & 119 & 144 & 176 \\
Feed/sWU cost ratio & 0.86 & 0.98 & 1.13 & 1.31 & 1.51
\end{tabular}




\section{Unit Costs for Enriched Uranium}

Having discussed the parameter feed/SWU cost ratio, let us now consider the trends in unit costs for enriched uranium ( $\$ / \mathrm{kg} U$ ) as a function of that parameter and also as a function of changes in transaction tails assay.

Figure 4 is a plot of unit costs for highly enriched uranium $(93.15 \%$ $235 \mathrm{U}$ ) as a function of the feed/SWU cost ratio for two values for transaction tails assay $(0.002$ and 0.003$)$ and for two costs for enrichment services ( $\$ 53.35$ and $\$ 100 / \mathrm{SWU})$. For the 0.002 transaction tails assay, Fig. 4 indicates that late 1975 custs for highly enriched uranium might range from a low of $\sim \$ 16,000 / \mathrm{kg} \mathrm{U}$, provided yellowcake is available at $\sim \$ 5.50 / 1 \mathrm{~b} \mathrm{U} \mathrm{U}_{3} 0_{8}$ $(\$ 12.13 \$ / \mathrm{kg})$ to a high of $\sim \$ 25,000 / \mathrm{kg} \mathrm{U}$, assuming one paid $\sim \$ 24.50 / 1 \mathrm{~b} \mathrm{U} \mathrm{U}_{3} 0_{8}$ $(\$ 54.02 / \mathrm{kg})$ for ore concentrates.

Note also that the slopes of the lines in Fig. 4 increase with increasing values for transaction tails assay. If the transaction tails assay were changed from 0.002 to 0.003 , the lines would intersect at a feed/SWU cost ratio of 0.8092 which is independent of enrichment; that is, if the product enrichment were $3 \%{ }^{235} \mathrm{U}$, or any other enrichment, the cost curves would still cross at the same feed/SWU cost ratio (see Appendix A for proof). Also as shown in Fig. 4, if the feed/SWU cost ratio is less than 0.8092 , increasing the transactions tails assay from 0.002 to 0.003 results in lower unit costs for enriched uranium. The savings from lower enrichment cost. (1ess SWUs required) outweigh cost increases from having to supply more natural uranium feed per kilogram of product. 'l'he reverse is true ac the higher feed/SWU cost ratios.

The unit price for highly enriched uranium, which includes changes in transactions tails assay, unit enriching costs, ore cost, and conversiun cost, may be obtained from Fig. 5. We illustrate the use of Fig. 5 by a numerical example. Suppose the unit cost for yellowcake is $\$ 17.73 / 1 b \mathrm{U}_{3} \mathrm{O}_{8}$ $(\$ 39.09 / \mathrm{kg})$ and conversion costs, including sampling and transportation charges, are $\$ 3.90 / \mathrm{kg}$ U. Excluding processing losses, feed cost is (17.73 $\times(2.6)+3.90 \cong \$ 50.0 / \mathrm{kg}$ for natural uranium delivered to the cascade. Assume that the charges for enrichment services are $\$ 100$ per SWU with 0.002 specified for transaction tails assay. The feed/SWU cost ratio is $(\$ 50.0 / \mathrm{kg}$ $U) \div(\$ 100 / \mathrm{SWU})=0.5$, and the ratio of enriched-uranium cost/SWU cost for 


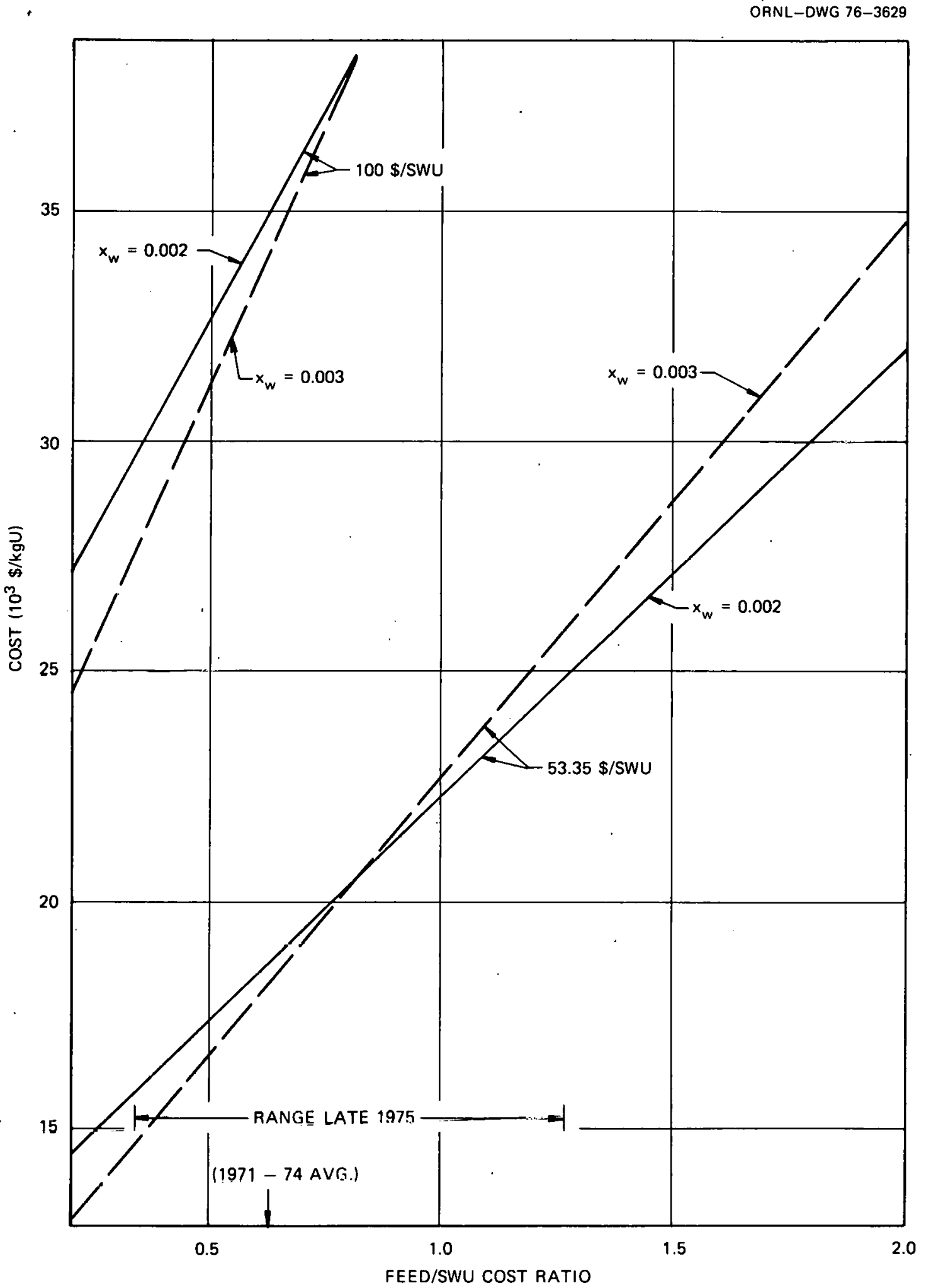

Fig. 4. Unit cost for enriched uranium (93.15\% ${ }^{235} \mathrm{U}$ content). 


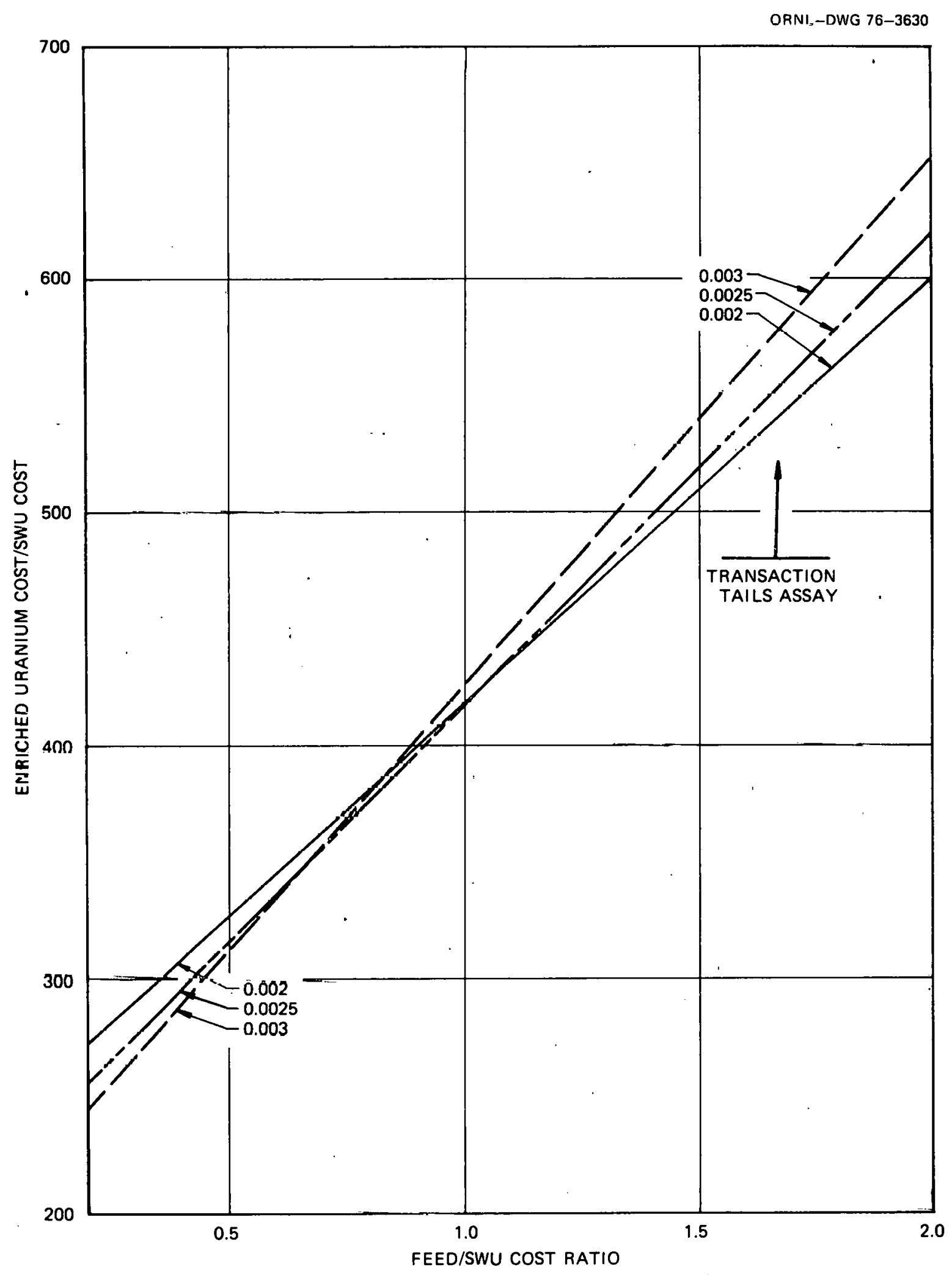

Fig. 5. Costs for $93.15 \%$-enriched uranium. 
0.002 tails assay is 327 . The price paid per kilogram of highly enriched uranium is $100 \times 327 \cong \$ 32,700 / \mathrm{kg}$. If the tails assay were 0.003 and ali other parameters the same as above, the price would be $\sim \$ 31,300 / \mathrm{kg}$.

The unit price for low-enrichment $\left(3.2 \%{ }^{235} \mathrm{U}\right)$ is presented in Fig. 6 . If, for a specified transaction tails assay and various feed/SWU cost ratios, we divide the unit cost for highly enriched uranium by that for low-enrichment uranium, the results shown in Fig. 7 are obtained. These results, calculated using Eq. (2), indicate that as the feed/SWU cost ratio increases, the ratio of unit costs for enriched uranium (93.15\% vs $3.2 \%$ )

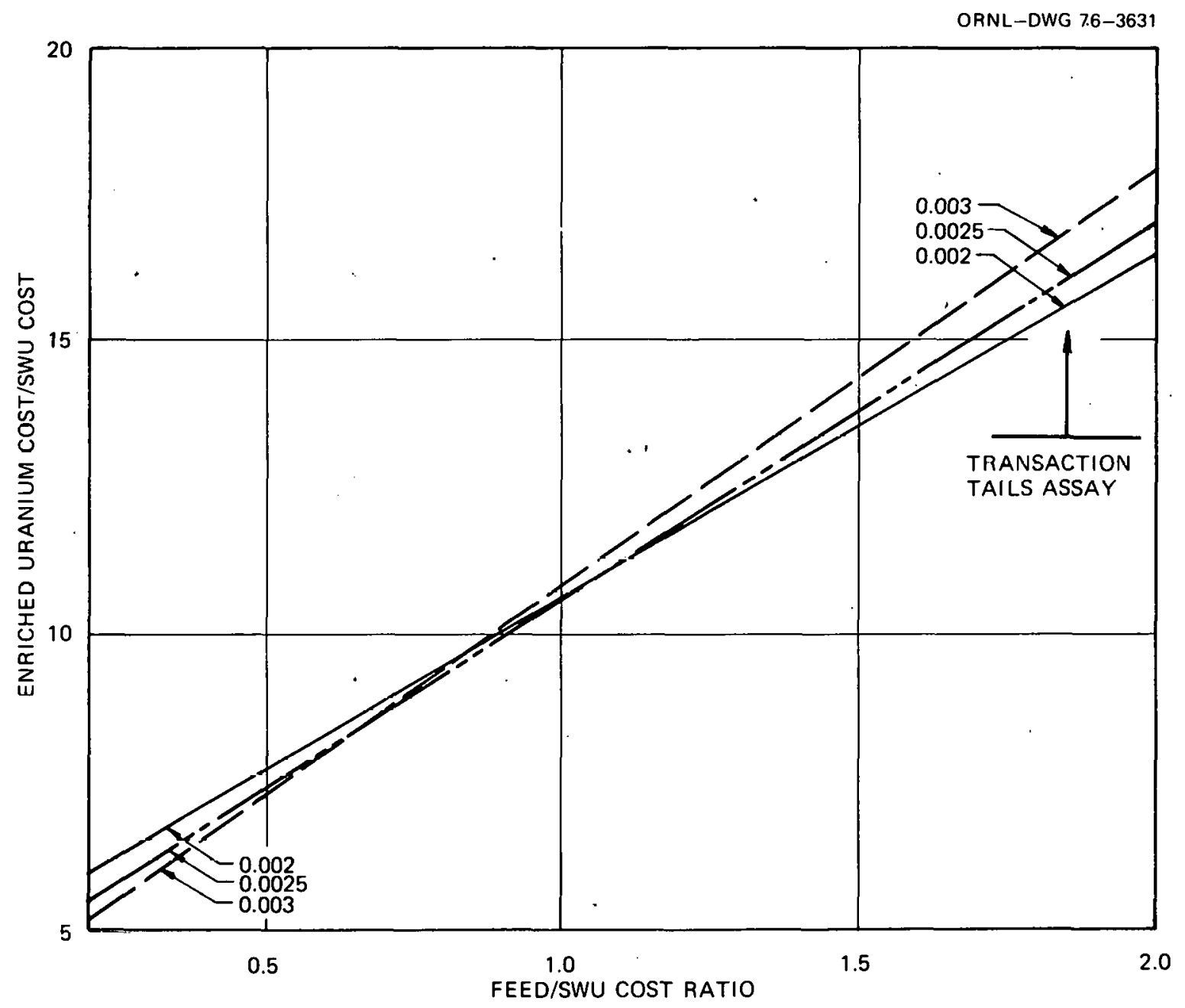

Fig. 6. Costs for $3.2 \%$-enriched uranium. 


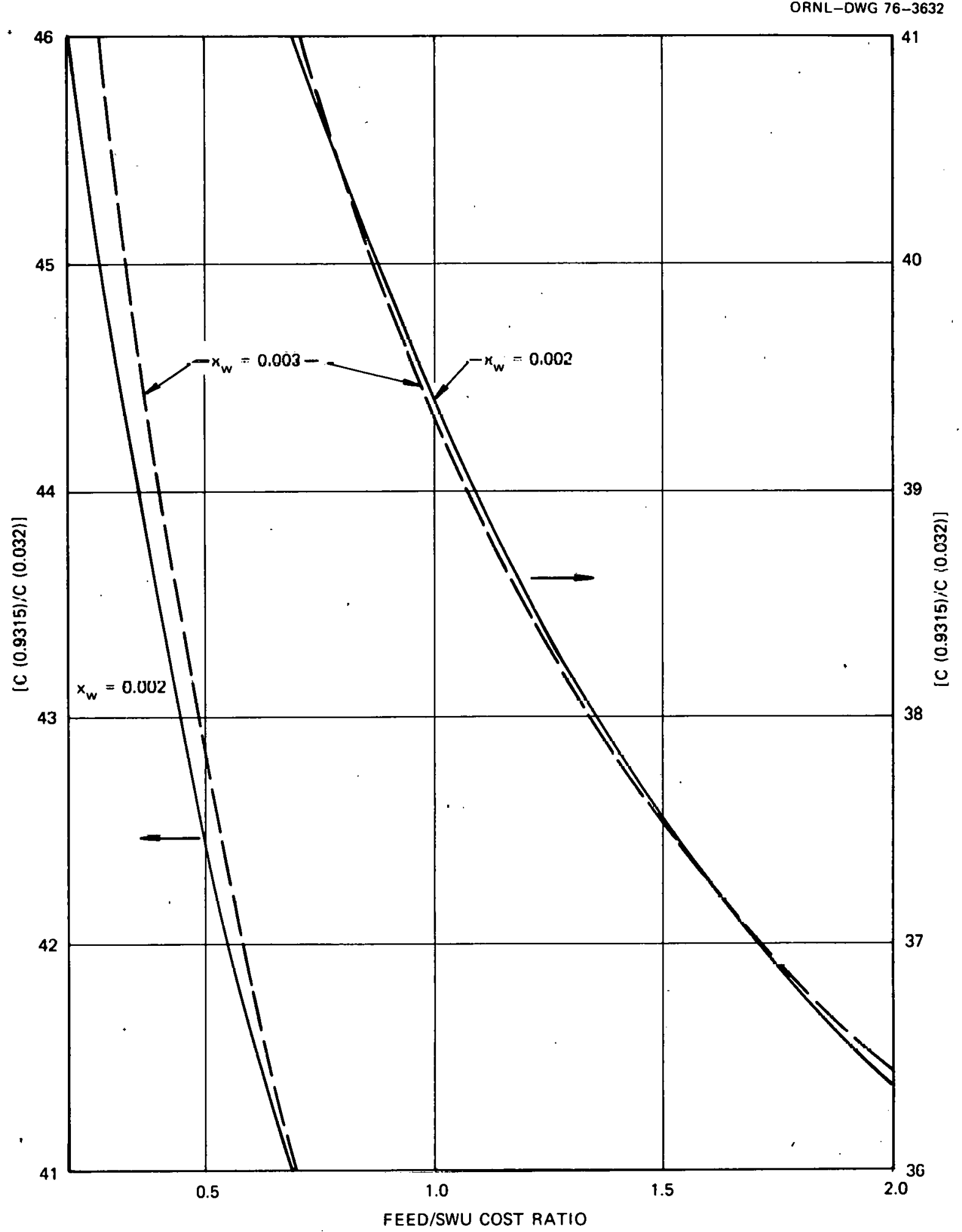

Fig. 7. Ratio of unit cost for $93.15 \%$-enriched uranium to $3.2 \%$ enriched uranium vs feed/SWU cost ratio. 
decreases. Another way to state the results from Fig. 7 would be as follows: If future costs for ore concentrates plus conversion costs (i.e., feed costs) increase more rapidly than the costs for enriching services (condition of increasing feed/SWU cost ratio), the unit cost for highly enriched uranium will increase percentagewise less than that for low-enrichment uranium. As will be shown by the following numerical examples, cost trends that result in increased feed/SWU cost ratios yield cost advantages for the HTGR fueled with highly enriched uranium. Finally, it should be evident from Fig. 7 that changes in the ratio of unit costs for enriched uranium are least sensitive to changes in transaction tails assay. Only $x_{w}=0.002$ and 0.003 are shown, whereas the first proposed change would be to 0.0025 , then to 0.00275 , and to 0.003 , each of which would produce results that generally would fall between the two curves shown in Fig. 7 .

\section{Loading Costs for HTGR vs PWR}

To calculate the kilograms of natural and enriched uranium required for replacement loadings for an HTGR and a PWR (with plutonium recycle), we used the data from Table 12 of Ref. 14 . For $0.2 \%$ tails assay and a $75 \%$ plant factor, the HTGR requires 0.085 short ton $\left(77.1 \mathrm{~kg}\right.$ ) of $\mathrm{U}_{3} \mathrm{O}_{8}$ per megawatt of electricity [MW(e)] per year, and the PWR requires 0.129 ton $(117.0 \mathrm{~kg})$ which includes 0.0067 ton $(6.08 \mathrm{~kg}$ ) for natural uranium to be spiked with plutonium. ${ }^{14}$ The HTGR uses thorium as fertile material, reloading $15 \sim 7.194 \mathrm{~kg}$ per megawatt [MW(e)] per year with an annual consumption of $20.64 \mathrm{~kg}$ per megawatt [MW(e)]. These data formed the basis for the annual loadings shown in Table 2 for the 1000-MW(e) HTGR and the 1000-MW(e) PWR.

In the following cost analysis, we shall first ignore the PWR costs for natural uranium used as spiking material and the HTGR costs for thorium and concentrate on comparing the costs for enriched uranium. The unit costs for enriched uranium referred to in this analysis were obtained from Tables A2 and A4 of Appendix A assuming $0.2 \%$ tails assay. As a base, or reference, case, we use 1975 costs for enriching services for fixed-commitment contracts $(\$ 53.35 / \mathrm{SWU})$ and 0.8 for a feed/SWU 
Table 2. Uranium and thorium costs for a 1000-MW(e) HTGR and a 1000-MW(e) PWR

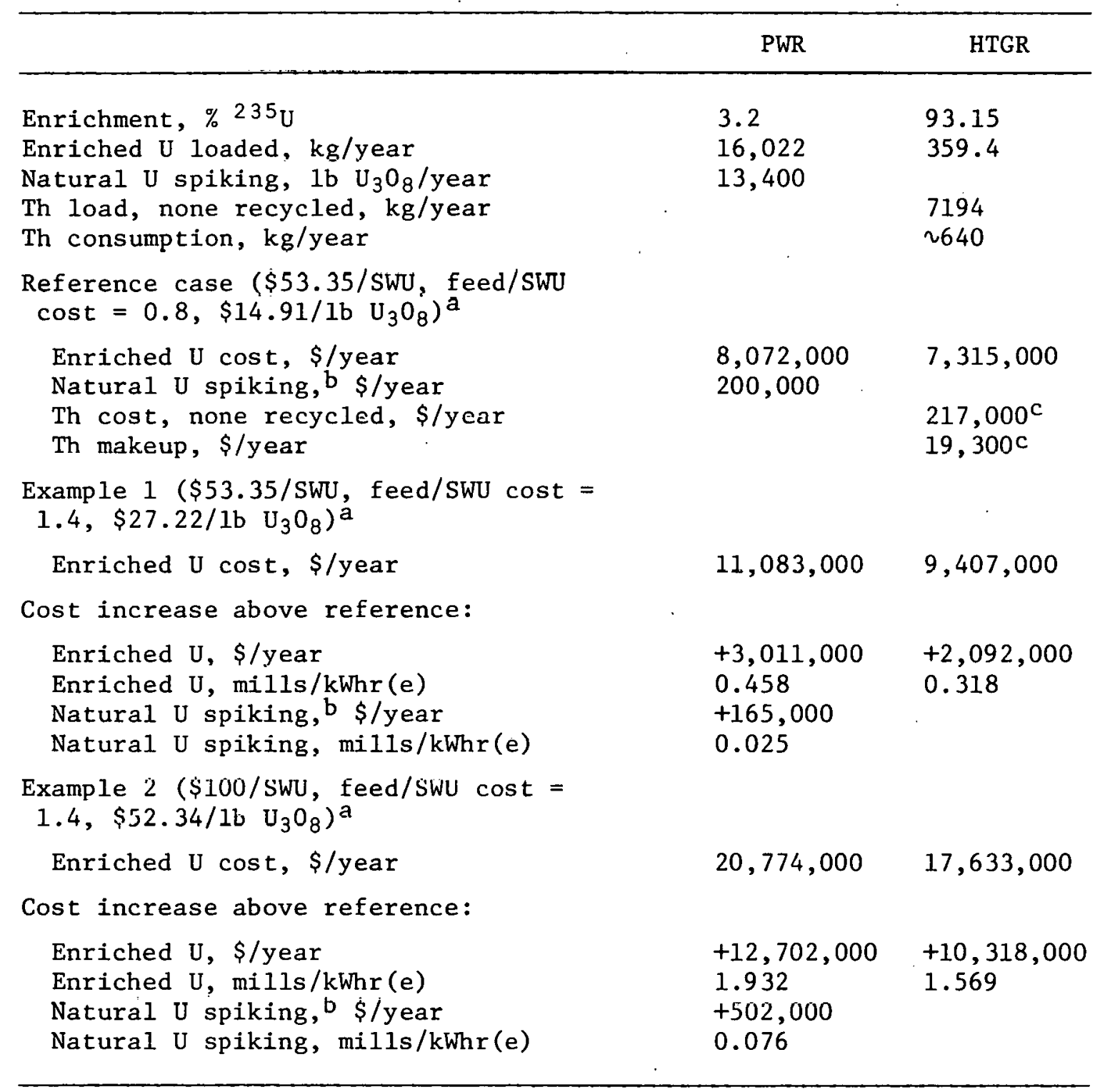

\footnotetext{
a Assuming conversion costs of $\sim \$ 3.90 / \mathrm{kg}$.

${ }^{b}$ As $\mathrm{U}_{3} \mathrm{O}_{8}$, cost for subsequent conversion not included.

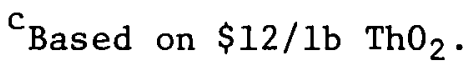


cost ratio. The price for natural uranium $(\$ 42.68 / \mathrm{kg})$ could result from a conversion cost of $\$ 3.90 / \mathrm{kg}$ quoted for late 1975 and $\$ 14.91 / 1 \mathrm{~b} \mathrm{U} \mathrm{U}_{3} \mathrm{O}_{8}$ $(\$ 32.88 / \mathrm{kg})$ for ore concentrates [approximately arithmetic average between highest and lowest cost in mid-1975 (see Fig. 2)]. These costs would yield a unit cost for $93.15 \%$ enriched uranium of $\$ 20,352.15 / \mathrm{kg}$ and would total approximately $\$ 7.3$ million for enriched uranium required to reload the HTGR; the unit cost for $3.2 \%$-enriched uranium of $\$ 503.79 / \mathrm{kg}$, totaling approximately $\$ 8$ million for enriched uranium required for reloading the PWR (see Table 2).

We want to compare the increase in cost for purchasing enriched uranium to reload an HTGR with that for a PWR as costs for enriching services and/or costs for ore concentrates rise. As a first example, we allow the cost for enriching services to remain at $\$ 53.35 /$ SWU and arbitrarily increase the feed/SWU cost ratio to 1.4 from 0.8 specified for the reference case. This example would represent a sudden increase in price for ore concentrates from $\$ 14.91 / 1 \mathrm{~b} \mathrm{U} \mathrm{U}_{3} 0_{8}(\$ 32.88 / \mathrm{kg})$ to $\$ 27.22 / 1 \mathrm{~b}(\$ 60.02 / \mathrm{kg})$ assuming conversion costs remained unchanged. Concentrate at $\$ 27.22 / 1 \mathrm{~b} \mathrm{U} \mathrm{U}_{3}$ is not far above the highest cost shown in Fig. 2 for late 1975. This assumed increase in ore cost would place the unit cost for $93.15 \%$-enriched uranium at $\$ 26,174.70 / \mathrm{kg}$ and would result in approximately $\$ 2$ million increase in cost for enriched uranium for reloading the HTGR. As can be seen in Table 2, the increase in cost for enriched uranium would be even larger for the PWR. At the higher ore cost, the unit cost for $3.2 \%$-enriched uranium would be $\$ 691.71 / \mathrm{kg}$, which would raise the cost for enriched uranium required to reload the PWR about $\$ 3$ million. Hence, the HTGR would be approximately $\$ 1$ million per year, or $0.14 \mathrm{mills} / \mathrm{kWh}(\mathrm{e})$, less sensitive to this assumed sudden increase in price for ore concentrates than the PWR.

As conditions for the second example, we use the same feed/SWU rnst. ratio (1.4) as above but allow the cost for enrichment services to increase from $\$ 53.35 /$ SWJ to an arbitrary choice of $\$ 100 /$ SWU. If conversion costs were assumed to remain at $\$ 3.90 / \mathrm{kg} U$, the unit cost for ore concentrates would be $\$ 52.34 / 1 \mathrm{~b} \mathrm{U} \mathrm{U}_{8}(\$ 115.40 / \mathrm{kg})$ to satisfy both the new costs for enriching services and the feed/SWU cost ratio. The unit costs for $93.15 \%-$ aild $3.2 \%$-enrlched uran1um would be $\$ 49,062.23$ and $\$ 1,296.56 / \mathrm{kg}$ respectively. 
Note that these unit costs are, respectively, $\sim 2.4$ and $\sim 2.6$ times the 1975 unit costs (reference case) for $93.15 \%$ - and 3.2\%-enriched uranium: Ore costs, $\sim \$ 50 / 1 \mathrm{~b} \mathrm{U} \mathrm{U}_{3} \mathrm{O}_{8}(\$ 110.25 / \mathrm{kg})$, and charges for separation work, $\sim 100 / \mathrm{SWU}$, are in line with some predictions for these costs expected to occur within the next 5 to 10 years. As can be seen by the data in Table 2, relative to the reference case, the cost for enriched uranium to reload the HTGR has increased $\sim \$ 10.3$ million, and that for the PWR has increased $\sim \$ 12.7$ million. The difference in these increases [ $\$ 2.4 \mathrm{million}$ or $0.36 \mathrm{mill} / \mathrm{kWhr}(\mathrm{e})$ ] shows that the HTGR is less sensitive than the PWR to the assumed increases in costs of ore and enrichment services. In the dbuve example, we used $0.2 \%$ tails assay, If we had used $0.3 \%$ tails assay in computing unit costs for enriched uranium in example 2; the conclusions would have been essentially the same; that is, the HTGR would have been $\sim \$ 2.6$ million per year less sensitive to the rising costs than the PWR.

In the discussions above, we did not consider reactor reoptimlzacton. The cost increase (above reference case) for enriched uranium required by the PWR could be somewhat less if the enrichment were reduced as the costs for both ore concentrates and separative work increase. However, a reduction in enrichment, assuming the amount of $235 \mathrm{U}$ in the core is held consțant, implies a larger PWR core and associated cost increase for cumpuntuts such as the pressure vessel. Shlle lle ibjective of rcoptimisation would be to minimize the cost for electricity (which includes capital costs and costs for all components of the fuel cycle), it is not clear what effect, if any, at.tempts at reoptimizing a PWK might have on the abuve PWR=HTGR cost comparison.

Table 2 also shows the costs for natural uranium to be spiked with plutonium in a PWR and the cost for fresh thorlum seluaded into an IITCR. The pricelb for nuclear grade, $9 y .9 \% \mathrm{lthO}_{2}$, during 1974 was repurted as $\$ 8$ to $\$ 12 / 1 \mathrm{~b} \mathrm{Th0} \mathrm{T}_{2}(\$ 20.07$ to $\$ 30.11 / \mathrm{kg})$. The higher unit cost was used to calculate the thorium costs shown in Table 2. If spent thorium is not reclaimed and reused in the HTGR, the cusL fus fresh thorium will bc approximately the same as the cost for natural uranium (as $\mathrm{U}_{3} 0_{8}$ excluding the cost for subsequent oxide conversion) required for mixing with plutonium in the PWR. If only the thorium consumed is to be replaced with fresh thorium, 
the costs for this makeup will be quite small for an HTGR. The cost increase for natural uranium spiking material (PWR) is also shown in Table 2 for each of the two examples, that is, as yellowcake prices are assumed to increase from $\$ 14.91 / 1 \mathrm{~b}$ to $\$ 27.22 / 1 \mathrm{~b}$ or $\$ 52.34 / 1 \mathrm{~b}$. As can be seen, the cost increase for this spiking material, relative to the cost increase for the $3.2 \%$-enriched uranium, is quite small for the PWR.

\section{CONCLUSIONS}

If natural uranium feed costs (i.e., cost for ore concentrates plus $\mathrm{U}_{3} \mathrm{O}_{8}$ to $\mathrm{UF}_{6}$ conversion costs) rise more rapidly in the future than costs for enrichment services, this trend toward increasing feed/SWU cost ratio will offer cost advantages for reactors such as the HTGR that use highly enriched uranium. The ratios of unit cost for highly enriched uranium to that for low-enrichment uranium decrease with increasing feed/SWU cost ratio (see Fig. 7). Under certain conditions, as illustrated by numerical examples, the cost increase for highly enriched uranium for loading HTGRs can be millions of dollars less than that for low-enrichment uranium required to load PWRs.

Over most of the range of feed/SWU cost ratios studied, an increase in transactions tails assay from 0.002 stepwise to 0.003 does not appear to offer any significant cost advantage or disadvantage for the HTGR relative to the PWR. The unit costs for highly enriched uranium and for low-enrichment uranium may each either increase or decrease as the transaction tails assay is increased. If the feed/SWU cost ratio is less than 1.0188, the first announced increase (from 0.002 to 0.0025 ) will result in a unit cost decrease for both highly enriched uranium and low-enrichment uranium; feed/SWU cost ratios greater than 1.0188 will cause the opposite effect (see F1gs, 5 and 6). 


\section{THIS PAGE WAS INTENTIONALLY \\ LEFT BLANK}


Appendix A

UNIT COSTS FOR ENRICHED URANIUM

The unit cost $(\$ / \mathrm{kg} U)$ paid for enriched uranium $\mathrm{C}_{\mathrm{e}}$ was expressed in Eq. (1) of the text as follows:

$$
c_{e}=c_{f} x_{f}+c_{s} x_{s}
$$

where $C_{f}$ is the cost of natural uranium $(\$ / \mathrm{kg})$ at the cascade feed station and $C_{S}$ is the cost for enriching services ( $\$ / S W U$ ).

The feed component, kilograms of natural uranium feed per kilogram of enriched uranium product, is

$$
x_{f}=\left(x_{p}-x_{w}\right) /\left(x_{f}-x_{w}\right),
$$

where

$$
\begin{aligned}
& x_{p}=\text { product enrichment, wt } \%{ }^{235} U(\text { e.g., } 0.9315,0.032 \text { etc.), } \\
& x_{w}=\text { tails enrichment, wt } \% 235 U(\text { e.g., } 0.002,0.0025 \text { etc.), } \\
& x_{f}=\text { natural uranium feed enrichment, wt } \%{ }^{235} U(0.00711) .
\end{aligned}
$$

The separative work component, SWU/kg of enriched uranium product, is defined as

$$
\mathrm{X}_{\mathrm{s}}=\phi_{\mathrm{p}}+(\mathrm{W} / \mathrm{P}) \phi_{\mathrm{W}}-\mathrm{X}_{\mathrm{f}} \phi_{\mathrm{f}},
$$

where

$$
\begin{aligned}
\phi_{p} & =\left(2 x_{p}-1\right) \ln \left[x_{p} /\left(1-x_{p}\right)\right], \\
\phi_{w} & =\left(2 x_{w}-1\right) \ln \left[x_{w} /\left(1-x_{w}\right)\right], \\
\phi_{f} & =\left(2 x_{f}-1\right) \ln \left[x_{f} /\left(1-x_{f}\right)\right], \\
W / P & =\left(x_{p}-x_{f}\right) /\left(x_{f}-x_{w}\right) .
\end{aligned}
$$

The numerical values for feed component, separative work component, and other terms appearing in the cost equations are shown in Table Al. These values have been computed for highly enriched uranium $\left(93.15 \%{ }^{235} \mathrm{U}\right)$ and for low-enrichment uranium $(3.0,3.2$, and $3.5 \% 235 \mathrm{U})$ and include anticipated transaction tails assays from 0.002 to 0.003 . Tables Al through A6 were prepared from machine listings. The terms appearing in each table 
Table Al. Numerical values for terms in the unit cost equation

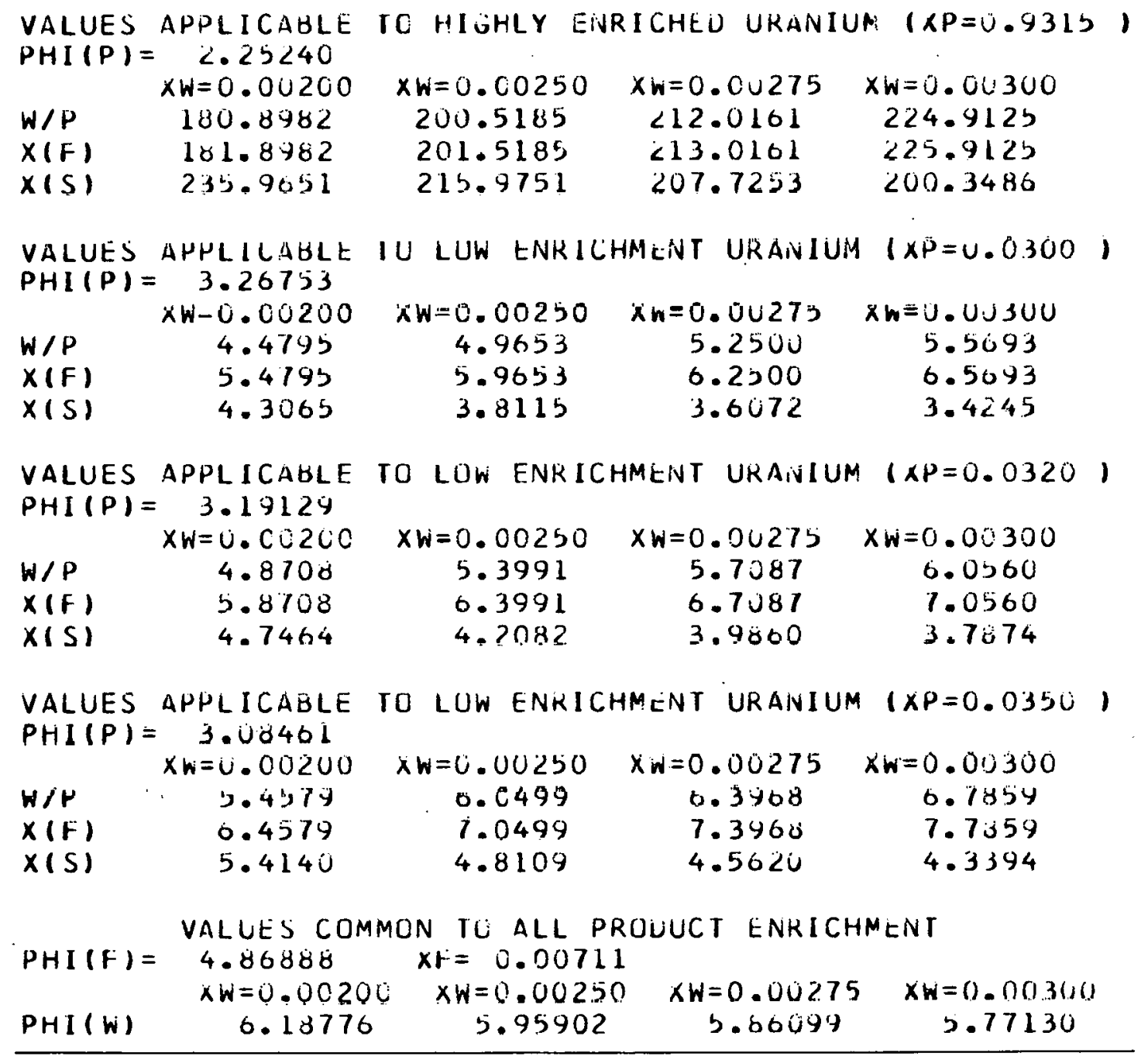


Table A2. Unit costs for highly enriched uranium $(X P=0.9315)$

\begin{tabular}{|c|c|c|c|c|}
\hline \multicolumn{5}{|c|}{$\begin{array}{l}\$ / S W U=53.35 \\
X P=0.9315: X F=0.00711\end{array}$} \\
\hline (FEED/SWU) & $x W=0.00<00$ & $x W=0.00250$ & $x_{W}=0.00275$ & $x w=0.30300$ \\
\hline 0.200 & 14524.39 & 13672.46 & 13355.02 & 13099.08 \\
\hline 0.400 & 16470.44 & 15022.06 & 15621.90 & 15309.57 \\
\hline 0.600 & 18411.29 & 17972.86 & 17900.78 & 17920.05 \\
\hline 0.800 & 20352.15 & 20123.077 & 20173.07 & 20330.54 \\
\hline 1.000 & 22293.00 & 22273.27 & 22446.53 & 22741.02 \\
\hline 1.200 & 24233.00 & 24423.47 & 24719.42 & 25131.51 \\
\hline 1.400 & 26174.70 & 26573.07 & 26992.30 & 27561.99 \\
\hline 1.600 & 28115.55 & 28723.88 & 29265.19 & $29 \div 72.47$ \\
\hline $1.80 \mathrm{C}$ & 30056.40 & 30874.07 & 31538.06 & 32382.96 \\
\hline 2.000 & 31997.27 & 33024.20 & 33810.96 & 34793.45 \\
\hline 2.200 & 33438.12 & 35174.48 & 36083.63 & 37203.73 \\
\hline$\$ / S W U=$ & & & & \\
\hline & $X F=0.00711$ & & & \\
\hline & UNIT COST FOR & ENRICHED U & JRANIUM $(\$ / K G$ & $U$ AS UFGI \\
\hline (FEED/SWU) & $X W=0.00200$ & $X W=0.00250$ & $X w=0.00275$ & $X W=0.00300$ \\
\hline 0.200 & 27234.41 & 25027.86 & 23032.85 & 24553.11 \\
\hline 0.400 & 30872.43 & 29658.23 & 29293.16 & 29071.36 \\
\hline 0.600 & 34510.40 & 33088.60 & 33553.49 & 33589.60 \\
\hline 0.800 & 38143.36 & 37118.97 & 37813.82 & 38107.86 \\
\hline 1.000 & 41786.33 & 41749.34 & 42074.14 & 42026.10 \\
\hline 1.200 & 45424.29 & 45779.71 & 46334.45 & 47144.36 \\
\hline 1.400 & 49002.23 & 49810.08 & 50594.77 & 51062.00 \\
\hline 1.000 & 52700.20 & 53340.45 & 54855.10 & 56180.63 \\
\hline 1.800 & 56338.16 & 57870.80 & 59115.40 & 60699.09 \\
\hline 2.000 & 59970.14 & 01901.20 & 03375.75 & 05217.36 \\
\hline .200 & 63614.11 & $05731 . .66$ & 67636.00 & 69735.56 \\
\hline
\end{tabular}


Table A3. Unit costs for low-enrichment uranium $(X P=0.0300)$

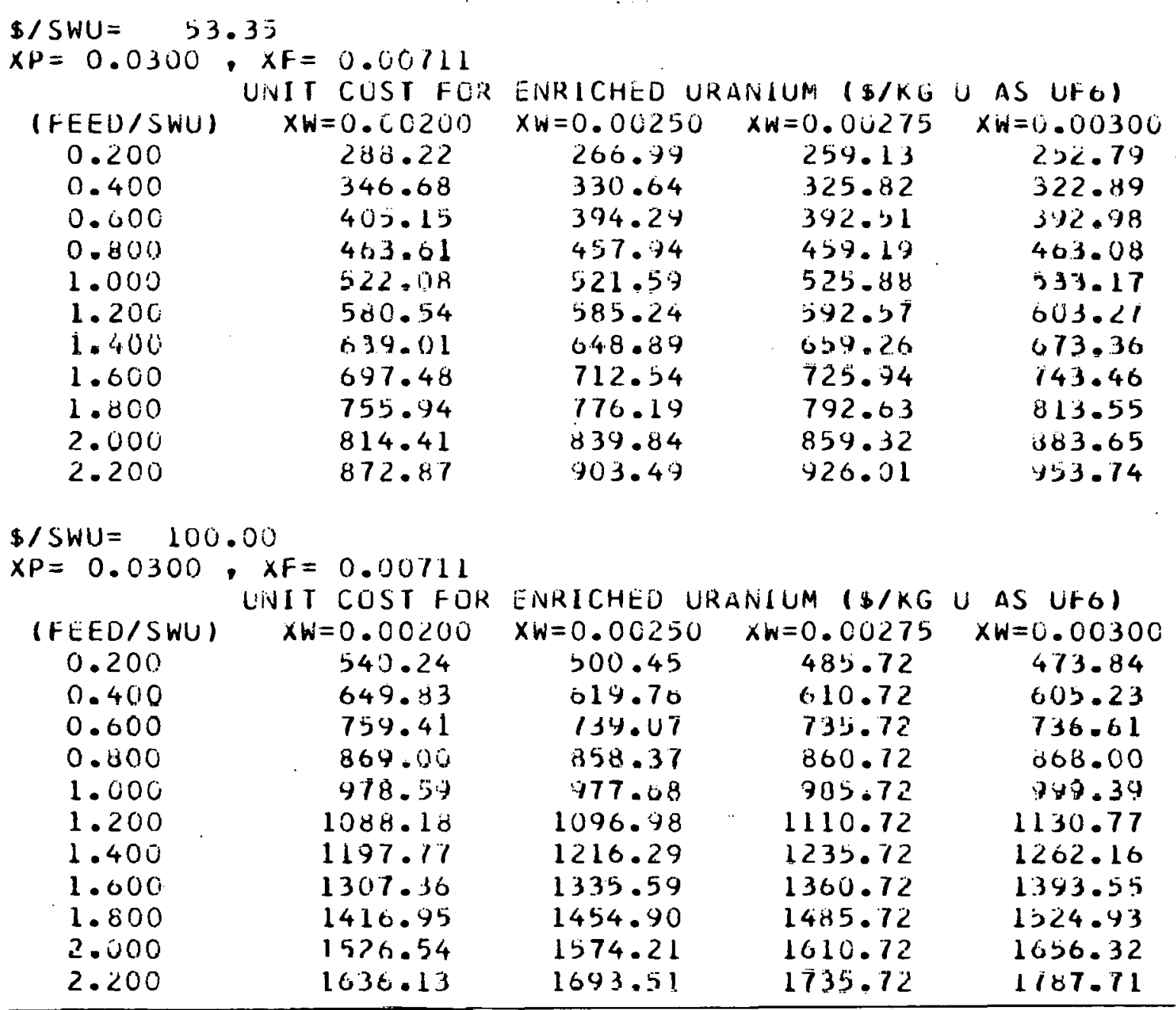


Table A4. Unit costs for low-enrichment uranium $(X P=0.0320)$

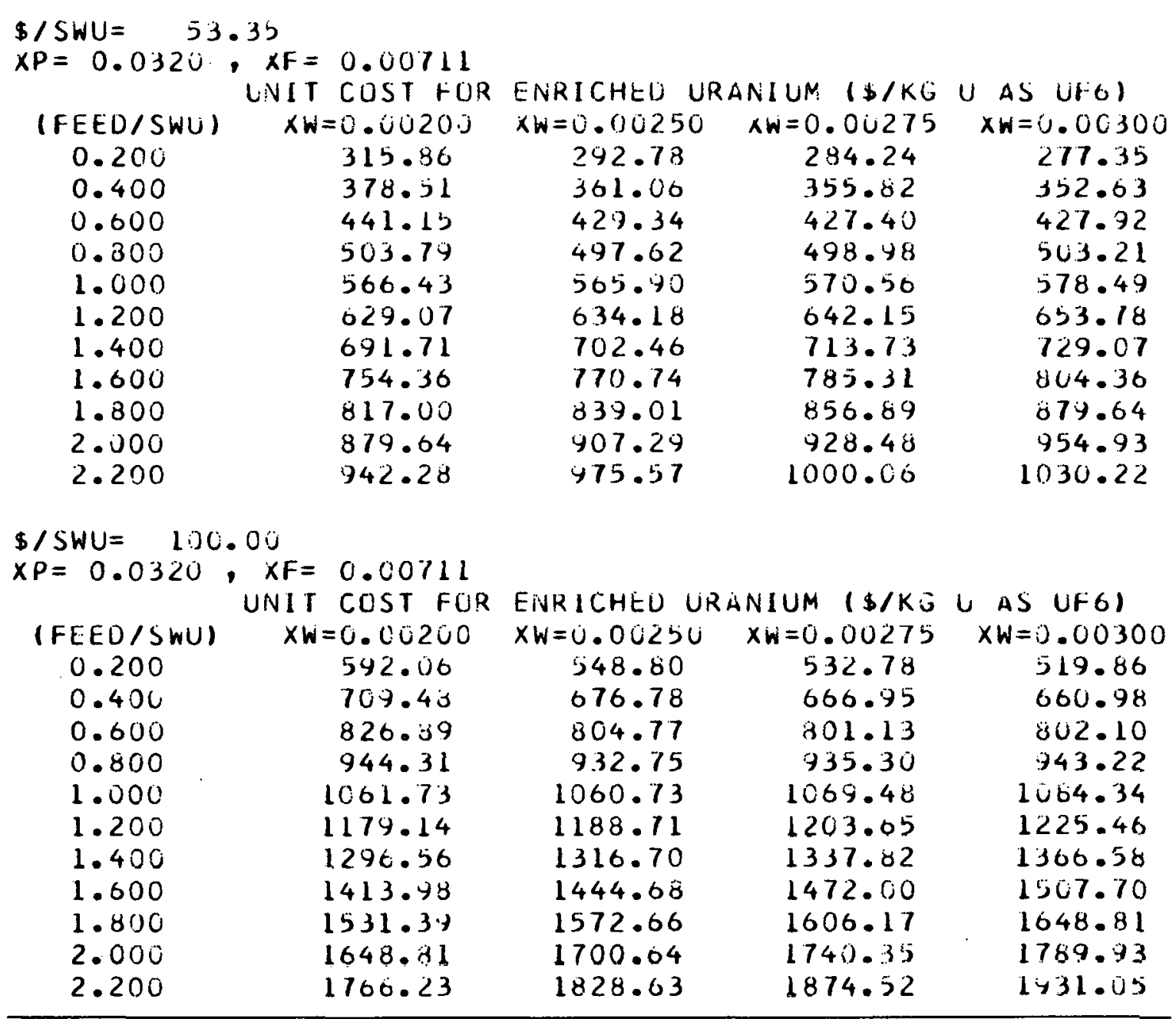


Table A5. Unit costs for low-enrichment uranium (XP=0.0350)

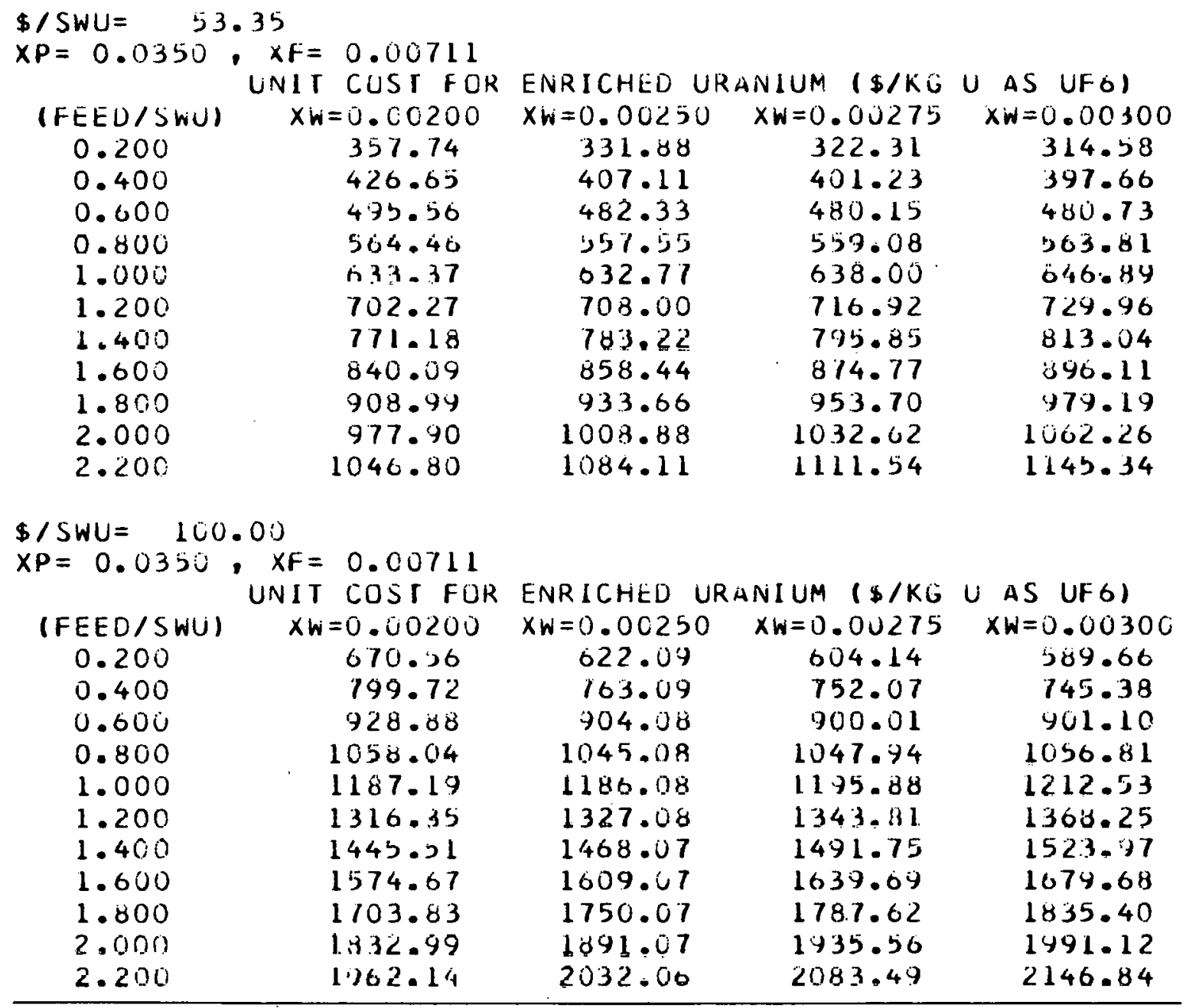


Table A6. Unit cost ratios for enriched uranium

\begin{tabular}{|c|c|c|c|c|}
\hline $\begin{array}{l}\text { (FEED/SWU) } \\
0.200 \\
0.400 \\
0.600 \\
0.800 \\
1.000 \\
1.200 \\
1.400 \\
1.600 \\
1.800 \\
2.000 \\
2.200\end{array}$ & $\begin{array}{r}93.15 \\
X W=0.00200 \\
50.41 \\
47.31 \\
45.44 \\
43.90 \\
42.70 \\
41.74 \\
40.90 \\
40.31 \\
39.70 \\
39.29 \\
38.88\end{array}$ & $\begin{array}{r}\text { PERCENT/ } 3 \\
\text { XW=0.00250 } \\
51.21 \\
47.85 \\
45.58 \\
43.94 \\
42.70 \\
41.73 \\
40.75 \\
40.31 \\
39.78 \\
39.32 \\
39.93\end{array}$ & $\begin{array}{l}3.00 \text { PERCENT } \\
\text { AW= U. O0275 } \\
51.34 \\
47.97 \\
45.61 \\
43.93 \\
42.68 \\
41.72 \\
40.94 \\
40.31 \\
3.9679 \\
39.35 \\
38.97\end{array}$ & $\begin{array}{r}A W=0.00301 \\
31.82 \\
48.03 \\
45.60 \\
43.90 \\
42.05 \\
41.69 \\
40.93 \\
40.31 \\
39.80 \\
39.37 \\
39.01\end{array}$ \\
\hline $\begin{array}{l}\text { (FEEU/SWU) } \\
0.200 \\
0.400 \\
0.000 \\
0.800 \\
1.000 \\
1.200 \\
1.400 \\
1.600 \\
1.800 \\
2.000 \\
2.200\end{array}$ & $\begin{array}{r}93.15 \\
\times W=0.00200 \\
46.00 \\
43.31 \\
41.74 \\
40.40 \\
39.36 \\
38.52 \\
37.34 \\
37.27 \\
30.79 \\
36.38 \\
36.02\end{array}$ & $\begin{array}{r}P E R C E N T / 3 \\
X W=0.00250 \\
46.70 \\
43.82 \\
41.80 \\
40.44 \\
39.36 \\
38.51 \\
37.83 \\
37.27 \\
36.80 \\
36.40 \\
36.06\end{array}$ & $\begin{array}{r}3.20 \text { HERCENT } \\
\times W=0.00 \angle 75 \\
46.99 \\
43.42 \\
41.30 \\
40.43 \\
39.34 \\
38.49 \\
37.82 \\
37.27 \\
36.81 \\
36.42 \\
36.08\end{array}$ & $\begin{aligned} \wedge W=0.00300 \\
47.23 \\
43.78 \\
41.88 \\
40.40 \\
34.31 \\
38.47 \\
37.80 \\
37.26 \\
36.81 \\
36.44 \\
36.11\end{aligned}$ \\
\hline $\begin{array}{l}\text { FEEU/SWUI } \\
0.200 \\
0.400 \\
0.000 \\
0.000 \\
1.000 \\
1.200 \\
1.400 \\
1.600 \\
1.300 \\
2.000 \\
2.200\end{array}$ & 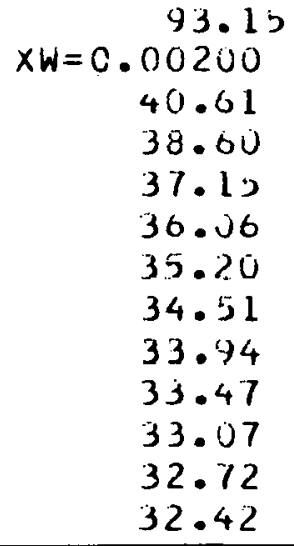 & $\begin{array}{r}\text { PERCENT/3 } \\
\text { XW=0.00250 } \\
41.20 \\
34.87 \\
37.26 \\
36.09 \\
35.20 \\
34.50 \\
33.93 \\
33.46 \\
33.07 \\
32.73 \\
32.45\end{array}$ & $\begin{array}{r}3.5 U \text { PEKCENI } \\
\times W=0.00275 \\
41.44 \\
38.95 \\
37.28 \\
36.08 \\
35.18 \\
34.48 \\
33.92 \\
33.45 \\
33.07 \\
32.74 \\
32.46 \\
3\end{array}$ & $\begin{array}{r}x w=0.00300 \\
41.04 \\
39.00 \\
37.28 \\
36.06 \\
35.15 \\
34.46 \\
33.90 \\
33.45 \\
33.07 \\
32.75 \\
32.48 \\
\end{array}$ \\
\hline
\end{tabular}


are as similar as possible, consistent with machine output, to the symbols appearing in Eqs. (A1) to (A3) and hopefully are recognizable (e.g., $X(F)=$ $\mathrm{X}_{\mathrm{f}} ; \mathrm{X}(\mathrm{S})=\mathrm{X}_{\mathrm{s}} ; \mathrm{XW}=\mathrm{x}_{\mathrm{w}} ; \mathrm{PHI}(\mathrm{P})=\phi_{\mathrm{p}}$, etc.).

Unit costs for highly enriched uranium $(93.15 \% 235 \mathrm{U})$ as a function of transaction tails assay and feed/SWU cost ratio and for two costs for enrichment services ( $\$ 53.35 /$ SWU and $\$ 100 /$ SWU) are shown in Table A2. Unit costs for low-enrichment uranium, $3.0 \%{ }^{235} \mathrm{U}, 3.2 \%{ }^{235} \mathrm{U}$, and $3.5 \%{ }^{235} \mathrm{U}$, are shown in Tables A3, A4, and A5, respectively.

Table A6 displays the ratio of unit cost for highly enrirhed uranium to that for low-enrichment uranium. The results with $3.2 \% 235$ to were incorporated into Fig. 7.

\section{Indifference Feed/SWU Cost Ratio}

As shown in Figs. 5 and 6 , as the transactions tails assay values are changed (i.e., from 0.002 to 0.0025 to 0.00275 to 0.003 ), the linear functions relating the ratios $\left(\mathrm{C}_{\mathrm{e}} / \mathrm{C}_{\mathrm{s}}\right)$ vs $\left(\mathrm{C}_{\mathrm{f}} / \mathrm{C}_{\mathrm{s}}\right)$ will intersect at specific feed/SWU cost ratios, some unique value for the ratio $C_{f} / C_{s}$. At this "indifference" ratio, changing the transaction tails assay results in no change in the unit price paid for enriched uranium. If the price paid for ore concentrates, conversion, and enrichment services are such that the feed/SWU cost ratio $\left(\mathrm{C}_{\mathrm{f}} / \mathrm{C}_{\mathrm{s}}\right)$ is greater than this "indifference" ratio, then increasing the transaction tails assay results in an increase in unit cost for enriched uranium and a reduction in unit cost for enriched uranium if the feed/SWU cost ratio is less than the "indifference" ratio. The "indifference" ratio is independent of $235 \mathrm{U}$ enrichment $x_{p}$; it is dependent only on $x_{f}$, the current transaction tails assay before change $x_{w}$, and the transaction tails assay after change $x_{w}^{*}$.

The independence of $x_{p}$ can be provied as follows: Divide Eq. (AL) by $\mathrm{C}_{s}$ and require the ratio $\mathrm{C}_{\mathrm{e}} / \mathrm{C}_{\mathrm{s}}$ to remain constant as $\mathrm{x}_{\mathrm{w}}$ is changed to $\mathrm{x}_{\mathrm{w}}^{*}$; then solve for the feed/SWU cost ratio $\mathrm{C}_{\mathrm{f}} / \mathrm{C}_{\mathrm{s}}$ :

$$
\frac{C_{f}}{C_{s}}=\frac{x_{s}^{*}-X_{s}}{x_{f}-X_{f}^{*}}=\phi_{f}+\left[\left(x_{f}-x_{w}\right) \phi_{w}^{*}-\left(x_{f}-x_{w}^{*}\right) \phi_{w}\right] /\left(x_{w}-x_{w}^{*}\right) \text {. }
$$


The term $\phi_{f}$ is a function only of $x_{f} ; \phi_{w}$ is a function of transaction tails assay $x_{w}$ before change; and $\phi_{w}^{*}$ is a function of transaction tails assay $x_{w}^{*}$ after change.

The following table lists solutions to the above equation when considering several possible changes in the transaction tails assay.

Change in transaction tails assay

0.002 to 0.0025

0.0025 to 0.00275

0.00275 to 0.003

0.002 to 0.003
Indifference feed/SWU cost ratio

1.01884

0.71754

0.57201

0.80921 


\section{THIS PAGE WAS INTENTIONALLY LEFT BLANK}




\section{Appendix B}

HISTORICAL COSTS FOR ORE CONCENTRATES

This appendix acknowledges the sources of information appearing in Fig. 2. The presentation has been organized according to (1) prices paid by the former USAEC, (b) prices paid on the commercial market, and (3) projections. Where possible, unit prices paid each year starting with the earliest year is the intended format. Unit costs for ore concentrates (yellowcake) are usually reported in the literature in units of U.S. dollars per pound as $\mathrm{U}_{3} \mathrm{O}_{8}$. These units have been preserved in this appendix. If the reader desires to convert to metric, multiply each unit cost by 2.205 for units of dollars per kilogram of $\mathrm{U}_{3} 0_{8}$ or by 2.60 for dollars per kilogram of uranium.

\section{AEC Prices Paid for Ore Cuncentrates $\left(\mathrm{U}_{3} \mathrm{O}_{8}\right)$}

Before 1959

From 1955 to 1958, $\mathrm{U}_{3} 0_{8}$ prices ${ }^{12}$ were $\$ 12.38 / 1 \mathrm{~b}(\sim \$ 30 / 1 \mathrm{~b}$ in 1975 do1lars). Canadian geologist Lattazil7 placed the 1952 to 1956 price in excess of $\$ 11 / 1 b$ and also stated that much of the uranium presently produced (1975) in the western world continues to come from long-standing facilities which were amortized at prices such as these.

1959

Franklin 18 reported that the AEC paid $\$ 9.40 / 1 \mathrm{~b}$ for domestic concentrates, $\$ 10.87 / 1 \mathrm{~b}$ for Canadian, and $\$ 11.84 / 1 \mathrm{~b}$ for other foreign (presumably South African).

$\underline{1960}$

According to Bernick, 19 the $\Lambda \mathrm{EC}$ paid $\$ 8.99 / 1 \mathrm{~b}$ for domestic, $\$ 11.04 / 1 \mathrm{~b}$ for Canadian, and $\$ 12.01 / 1 b$ for "overseas" (presumably South African). 1961

Bernick 20 listed AEC prices at $\$ 8.31 / 1 b$ average for domestic and $\$ 11.20 / 1 b$ for South African concentrates. 
$\underline{1961-1963}$

Bernick ${ }^{21}$ reported average $\mathrm{U}_{3} 0_{8}$ prices paid in fiscal $62-63$ as $\$ 7.85 /$ $1 b$ (domestic), $\$ 9.77 / 1 b$ (Canadian), and $\$ 11.29 / 1 b$ (South African). $\underline{1963-1964}$

Bracklin ${ }^{22}$ quoted AEC prices paid in fiscal 64 for average domestic as $\$ 8.03 / 1 b$, Canadian as $\$ 8.79 / 1 b$, and South African as $\$ 11.32 / 1 b$.

\section{$\underline{1964-1965}$}

Sherman 23 reported AEC prices paid for concentrates during fiscal 65 as $\$ 8.03 / 1 b$ for domestic, $\$ 8.73$ for Canadian, and $\$ 11.08$ for South $\Lambda$ frican. $\underline{1966-1970}$

Hogerton's paper 6 (May 1975) put a flat price of $\$ 8 / 1 b \mathrm{U}_{3} 0_{8}$ for the years 1964 through 1968 and an average price of $\$ 5.85 / 1 b$ during the stretchout phase (1969 to 1970).

Bernick24 (Feb. 1963) quoted the "new" AEC prices would be $\$ 8 / 1 \mathrm{~b}$ from Mar. 31, 1962, through 1968 and then no more than $\$ 6.70 / 1 b$ in 1969 and 1970.

\section{Commercial Prices Paid for Ore Concentrates $\left(\mathrm{U}_{3} \mathrm{O}_{8}\right)$}

\section{$\underline{1966-1968}$}

Sherman $^{25}$ reported early sales as ranging from $\$ 4$ to $\$ 6 / 1 b$ during 1966 and early 1967. Warren and Steyn ${ }^{26}$ placed the worth of uranium concentrates in 1967 at $\$ 6.00$ to $\$ 6.50 / 1 b$. Shcrman 27 reported a 1967 average price for Canadian $\mathrm{U}_{3} \mathrm{O}_{8}$ of $\$ 6.40 / 1 \mathrm{~b}$.

\section{$\underline{1968-1972}$}

Sherman ${ }^{27}$ listed some privace sales for the near term as follows:

\begin{tabular}{cccc} 
Firm & Contract dates & Price $\left(\$ / 1 \mathrm{~b} \mathrm{U} \mathrm{U}_{3} 0_{8}\right)$ \\
\cline { 2 - 2 } Kerr-McGee & $1968-1970$ & 5.85 \\
& $1970-1973$ & 6.45 \\
Utah Construction & $1968-1971$ & 5.39 \\
and Mining & $1972-1975$ & 6.425 \\
United Nuclear & $1969-1977$ & 6.14
\end{tabular}

Corporation 
$\underline{1972-1974}$

Concentrates making the open market in 1972 and 1973 often sold for $\$ 6.25 / 1 b$, frequently less than the cost of mining and milling it. 12 Gordon $^{28}$ reported spot prices at $\$ 6.00$ to $\$ 6.50$ per pound for 1972 and an average price ${ }^{7}$ of $\$ 7.10$ per pound for near-term deliveries in 1973 . 1974,1975

There was a considerable spread between the high and low costs for concentrates during the years 1974 and 1975. Contracts written in prior years for delivery during these years were at prices much lower than those specified in new contracts for immediate or near-term delivery.

The AEC survey ${ }^{29}$ of contracts made from 1967 to mid-1974 places the average 1974 cost at $\$ 7.65 / 1 \mathrm{~b}$. The ERDA survey, ${ }^{8}$ a year 1 ater, of contracts made from 1967 to mid-1975 increased the average 1974 cost to $\$ 7.90 / 1 b$.

During 1974, Western Nuclear ${ }^{9}$ received a letter of intent for 1974 deliveries priced at $\$ 9 / 1 b$ and 1975 delivery at $\$ 10 / 1 b$, subject to escalation. TVA 30 picked up its yellowcake opt1on with United Nuclear, for delivery in the late seventies, at something over $\$ 13 / 1 \mathrm{~b}$ in 1975 dollars. General Electric ${ }^{10}$ was offering (mid-1975) slightly more than $\$ 12 / 1 \mathrm{~b}$ to small-scale producers in the Colorado P1ateau area; Union Carbide was paying a little less than $\$ 5 / 1 b$. Washington Public Power Supply System ${ }^{31}$ contracted with Canada's Rio Algom for late 1975 delivery at $\$ 22 / 1 \mathrm{~b}$. Washington Public Power Supply System ${ }^{11}$ also awarded a contract (June 1975) to Western Nuclear for 1979 Lu 1983 delivery at the current price of $\$ 22 / 1 b$, subject to escalation.

In May 1974, Nuclear Exchange Corporation ${ }^{32}$ forecast $\$ 11.25 / 1 \mathrm{~b}$ for 1975 delivery. A year later Nuclear Exchange Corporation ${ }^{33}$ placed the immediate delivery cost in May 1975 at $\$ 20 / 1 b$, and it jumper ${ }^{34}$ to $\$ 24.70 / 1 b$ In early August 1975 .

\section{Surveys and Projections}

The former AEC and ERDA have each conducted surveys and reported weighted average uranium prices. The AEC results, ${ }^{29}$ reported 0ct. 22 , 1974, reflect contracts with duillestic producers made from 1967 through 
mid-1974; ERDA $^{8}$ results, reported Sept. 9, 1975, reflect contracts with domestic producers made from 1967 through mid-1975. The averages reported were not claimed to represent prices at which uranium may be purchased "now or in the future." The average prices per pound (estimated in current dollars) as they appeared in each reference are reproduced below:

\begin{tabular}{ccc} 
& \multicolumn{2}{c}{ Average cost $\left(\$ / 1 b \mathrm{U}_{3} 0_{8}\right)$} \\
\cline { 3 - 3 } Calendar year & Ref. $29(1974)$ & Ref. $8(1.975)$ \\
\hline 1974 & 7.65 & 7.90 \\
1975 & 7.85 & 8.45 \\
1976 & 8.80 & 10.20 \\
1977 & 9.25 & 10.75 \\
1978 & 9.60 & 12.05 \\
1979 & 10.50 & 13.10 \\
1980 & 11.40 & 13.80 \\
1981 & & 16.65 \\
1982 & & 19.20
\end{tabular}

Nuclear Exchange Corporation has also released estimates of future prices for yellowcake. The unit prices as they appeared in each reference are reproduced beluw:

Year of
delivery

1975

1977

Mid-1977

Mid 1.978

1979

Mid-1979

1980

1981

1983
Eslimated cost $\left(\$ / 1 \mathrm{~b} \quad \mathrm{U}_{3} 0_{H}\right)$

Ref. 32 (May 1974) Ref. 33 (May 1975)

$$
11.25
$$

14.00

24.60
$16.00 \quad 27.05$

29.50
31.55

18.25

19.75

One U.S. uranium supplier ${ }^{11}$ says that a price of $\$ 50 / 1 b$ estimated for 1985 will be on the low side. 


\section{REFERENCES}

1. ERDA News Release, June 25, 1975, from Public Affairs Office.

2. U.S. Atomic Energy Commission, "The Nuclear Industry 1970," prepared for the Atomic Industrial Forum Conference, Washington, D.C., Nov. 18,1970 .

3. ERDA News Release No. 16, June 27, 1975, from Public Affairs Office.

4. The Nuclear Industry 1974, WASH-1174-74.

5. Nucleonics Week (July 3, 1975).

6. J. F. Hogerton, "U.S. Uranium Supply and Demand - Near Term and Long Range," Nucl. News, pp. 45-50 (May 1975).

7. Emanuel Gordon, "Uranium - New Development Is Targeted at the Future Nuclear Generating Market," Eng. Mining J., pp. 156-60 (March 1974).

8. ERDA News Release No. 33, Sept. 9, 1975.

9. Nucleonics Week (Apr. 18, 1974).

10. Ibid. (Aug. 21, 1975).

11. Ibid. (July 3, 1975).

12. "Colorado's Uravan Mineral Belt Booms Again as in the 50's," Nucz. Ind., pp. 28-29 (September 1975).

13. L.F.C. Reichle, "The Economics of Nuclear Power," presented to the New York Society of Security Analysts, Aug. 27, 1975.

14. Office of Planning and Analysis, United States Atomic Energy Commission, Nuclear Power Growth 1974-2000, WASH-1139(74), p. 24 (Feb. 14, 1974).

15. F.S.V. Progress Report for Period Ending June 30, GA-A12200 (1972).

16. R. V. Sondermayer, "Thorium - Waiting for Nuclear Fuel Market to Take Off," Eng. Mining J., pp. 19G-98 (March 1975).

17. Ann Maclachlan, "World $\mathrm{U}_{3} \mathrm{O}_{y}$ Going, Going, Almost Gone Says Canadian Geologist," Weekly Energy Keport, p. 8 (Sept. 29, 1975).

1.8. J. W. Franklin, "Uranium," Eng. Mining J., p. 108 (February 1960).

19. R. W. Bernick, "Uranium," Eng. Mining t., p. 88 (February 1961). 
20. Ibid., p. 91 (February 1962).

21. Ibid., P. 116 (February 1964).

22. Robert Bracklin, "Uranium," Eng. Mining J., p. 125 (February 1966).

23. John Sherman, "Uranium," Eng. Mining J., p. 108 (February 1966).

24. R. W. Bernick, "Uranium" Eng. Mining J., p. 115 (February 1963).

25. John Sherman, "Uranium," Eng. Mining J., p. 129 (February 1967).

26. F. H. Warren and J. J. Steyn, "Uranium Ore: Purchasing on the Long Term," Nucleonics 2b(4), 31-42 (Ap111 1967).

27. John Sherman, "Uranium," Eng. Mining J., p. 106 (March 1968).

28. Emanuel Gordon, "Uranium," Eng. Mining J., p. 126 (March 1973).

29. AEC News Release No. T505, Oct. 22, 1974.

30. Nucleonics Week (May 1, 1975).

31. Ibid. (May 1, 1974).

32. Ibid. (May 30, 1974).

33. Ibid. (May 8, 1975).

34. Ib1d. (Aug. 7, 1975). 


$$
\begin{gathered}
\text { ORNL/TM-5270 } \\
\text { UC-77 - Gas-Cooled Reactor } \\
\text { Technology }
\end{gathered}
$$

Interna1 Distribution

1. E. J. Allen

2. J. T. Bradbury

3. T. E. Cole

4. J. H. Coobs

5. W. E. Cooper

6. W. B. Cottrell

7. F. L. Culler

8. F. C. Davis

9. W. P. Eatherly

10. G. G. Fee

11. M. H. Fontana

12. Uri Gat

13. M. J. Goglia

14. C. C. Haws

15. H. W. Hoffman

16. F. J. Homan

17. J. P. Jarvis

18. J. D. Jenkins

19. M. S. Judd

20-21. P. R. Kasten

22. H. T. Kerr

23. R. W. Knoll

24. K. H. Lin

25. A. L. Lotts

26. R. E. MacPherson

27. W. J. McCarthy, Jr.

28. S. R. McNeany
29. J. M. Morrison

30. K. J. Notz

31. A. R. Olsen

32. W. H. Pechin

33. H. Postma

34. G. L. Ragan

35. J. E. Rushton

36. J. P. Sanders

37. Dunlap Scott

38. J. D. Sease

39. Myrtleen Sheldon

40. J. W. Snider

41. I. Spiewak

42. J. J. Taylor

43-47. W. E. Thomas

48. M. L. Tobias

49. D. B. Trauger

50. T. N. Washburn

51. G. D. Whitman

52. W. J. Wilcox

53. R. G. Wymer

54. R. M. Young

55. ORNL Patent office

56-57. Central Research Library

58. Document Reference Section

59-61. Laboratory Records Department

62. Laboratory Records (RC)

\section{External Distribution}

63-64. Director, Division of Nuclear Research and Application, ERDA, Washington, D.C. 20545

65. Director, Reactor Division, ERDA, ORO

66. Director, Research and Technical Support Division, ERDA, ORO

67-233. Technical Information Center, ERDA [For distribution as shown in TID-4500 under category UC-77, Gas-Cooled Reactor Technology (25 copies - NTIS)] 